Yun Ho Kim $\bowtie$

Dong Woo Jung

Hyung Do Song

Young Uk Won

Dong Ho Jung

https://doi.org/10.21278/TOF.451013720

ISSN 1333-1124

eISSN 1849-1391

\title{
EXPERIMENTAL STUDY ON COORDINATED HEADING CONTROL OF FOUR VESSELS MOORED SIDE BY SIDE
}

\begin{abstract}
Summary
A floating type liquefied natural gas (LNG) bunkering terminal has been under development in Korea since 2014; the terminal is designed to receive LNG from an LNG carrier (LNGC) and transfer it to two other LNG bunkering shuttles (LNGBS) simultaneously. The operational feasibility of the LNG loading and unloading processes has been confirmed. When four vessels are moored side by side with mooring ropes and fenders, their positions must be maintained within the designed allowable criteria. In addition, the floating bunkering terminal (FLBT) has its own mooring system, an internal turret with catenary mooring lines and stern tunnel thrusters to maintain its own position and control the vessel heading. In this study, we investigated the operational feasibility of the FLBT during the LNG loading and unloading operations with four vessel mooring configurations and heading controls. A series of model tests was done in the ocean engineering basin of the Korea Research Institute of Ships and Ocean engineering. The motion responses of the four vessels were determined using an optical measurement system, and the tensile loads on shipto-ship mooring ropes and the compressive loads on ship-to-ship fenders were measured using one-axis load cells. A white noise test was done and the results were compared with the numerical results for the purpose of validation. Then, four combined environmental conditions were presented both without heading control and with several heading control cases. Finally, we determined the available safe bunkering heading ranges taking into account the tensile loads on the mooring ropes.
\end{abstract}

Key words: $\quad$ Floating LNG bunkering terminal (FLBT); side-by-side mooring; heading control; ocean engineering basin test; bunkering operability

\section{Introduction}

The demand for energy resources has been steadily increasing with the explosive growth in world population over the last few decades. The next generation of solutions needs to be sustainable and clean as air pollution problems are highly prevalent nowadays. Renewable resources, such as solar, wind, and hydro, are viable solutions; however, the power production efficiency must be increased to replace conventional fossil fuels. Natural 


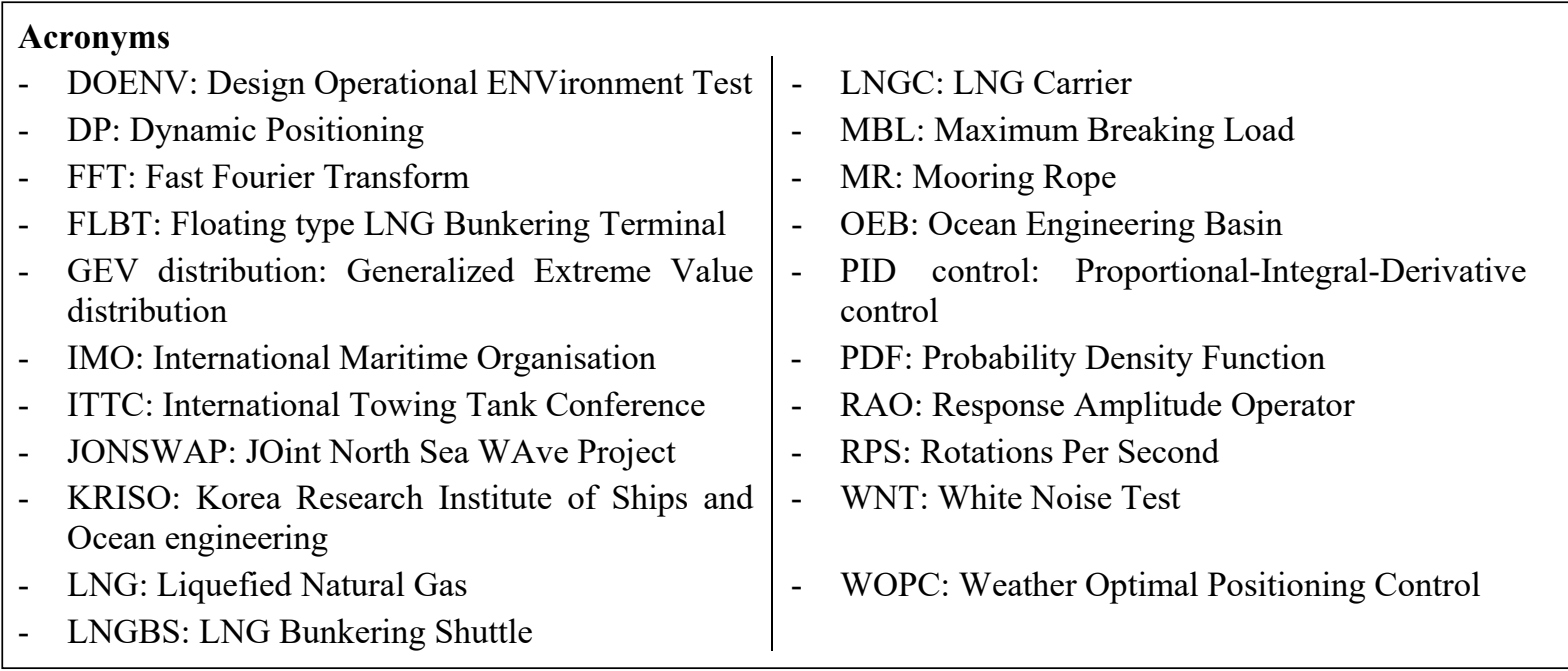

gas is practically regarded as an environmentally friendly energy resource as the emissions from this resource contain almost no sulphur. The 'sulphur cap' regulations of the International Maritime Organisation (IMO) on marine emissions was enforced from 1 January2020; consequently, it is planned for existing vessels to install scrubbers or convert their propulsion systems to liquefied natural gas (LNG)-fuelled engines. The regulations will be enhanced consistently, and the LNG-fuelled vessel industry is expected to grow significantly. Some issues regarding natural gas as a marine fuel were studied by Cockett [1] and Corbett et al. [2], and a study on the price competitiveness of LNG in comparison with conventional marine fuels was conducted by Schinas and Butler [3].

To promote the LNG-fuelled vessel industry, relevant infrastructures need to be prepared, including those of bunkering terminals. Since an onshore LNG terminal can explode, a new concept of offshore terminals has been considered. Since 2014, a national $\mathrm{R} \& \mathrm{D}$ project has been conducted in Korea to develop the core technology of floating type LNG bunkering terminals (FLBTs). This research is focused on the mooring system of FLBT at certain ocean sea operations, such as receiving LNG from an LNG carrier (LNGC) and unloading LNG to two smaller LNG bunkering shuttles (LNGBSs) simultaneously. The FLBT is self-moored by an internal turret and catenary mooring lines, while the stern tunnel thrusters are added to control the vessel headings. An LNGC and two LNGBSs are moored side by side to the FLBT with mooring ropes and fenders.

A number of studies were conducted on the multi-body interaction between vessels moored side by side. Ohkusu [4], Kodan [5], and Fang and Kim [6] applied the strip theory to the two-vessel problem as the vessels were located side by side and extremely close to each other. The two-dimensional problem was extended to a three-dimensional (3D) problem by Fang and Chen [7] by adopting the 3D source distribution method. Buchner et al. [8] also conducted a numerical study on the hydrodynamic characteristics of two vessels moored side by side with a rigid lid on the free surface. Hong et al. [9] compared the experimental and numerical results of the drift forces acting on three vessel configurations. The excessive effect of the gap flow in the boundary element method was practically suppressed by Huijismans et al. and Hong et al. [10,11]. Recently, computational fluid dynamics was applied to two vessels which were located close to each other in the studies done by Nam et al. and Koop $[12,13]$.

The second part of this study is the heading control, or weathervaning control. Many control algorithms have been studied in dynamic positioning (DP) systems, while few representative studies are listed. Pinkster and Nienhuis [14] discovered that the best heading control performance was achieved when the yaw rotating centre was located near the bow of 
the vessel. They then adopted a simple proportional-integral-derivative (PID) heading control method. Fossen and Strand [15] suggested a nonlinear weather optimal positioning control (WOPC) with polar coordinates and a back-stepping control design. The handbook written by Fossen [16] has been regarded as the motion control standard for environmental loads. Kim et al. [17] numerically investigated the weathervaning control for two vessels in a tandem mooring configuration.

Kim et al. [18] conducted a series of ocean engineering tests on models, which are directly related to this study; the tested configuration included a FLBT, a LNGC, and two LNGBSs moored side by side as the FLBT had not yet had a heading control system. Jung et al. [19] calculated the safe bunkering criteria when considering incoming wave headings. From previous studies, we have found that the range of incoming waves for the safe bunkering operation is extremely narrow. To increase the operational possibility of the LNG loading or unloading operations of an FLBT, we designed the stern tunnel thrusters for the FLBT to control its yaw motion. This study is an extensive experimental study on the evaluation of the FLBT heading control system to increase the operability of the LNG bunkering process. White noise waves and four combined ocean environments, including waves and currents, were considered. The motion responses of four vessels, tensile or compressive loads on ship-to-ship mooring ropes or fenders, and thrust forces on the stern tunnel thrusters were measured. Five different heading control conditions with the same environments, including a no control case, were examined. Finally, we calculated the range of possible LNG bunkering operations in terms of the structural reliability of the ship-to-ship mooring system.

\section{Experimental Setup}

\subsection{Vessels}

We conducted a series of tests on models in the ocean engineering basin (OEB) of the Korea Research Institute of Ships and Ocean engineering (KRISO). All models and physical quantities were scaled down by 1:65, according to the International Towing Tank Conference (ITTC) recommendations for model testing of offshore structures and the environmentgenerating capacity of the KRISO OEB. Figure 1 shows the general arrangement of the FLBT, LNGC, and two LNGBSs moored side by side with hawsers and fenders, and their relative positions. In addition, the LNG loading arms and corresponding manifolds are indicated by red circles and yellow triangles, respectively. The main particulars of the four vessels and their locations are listed in Table 1. The longitudinal centre of gravity is in the mid-ship section, and the positive direction is from the FLBT stern to its bow for all vessels. Also, the vertical centre of gravity is at the water surface level, and the positive direction is from the sea bottom to the sky for all vessels. The relative locations are illustrated by the earth-fixed coordinates of the FLBT. The $180^{\circ}$ heading angle denotes that the vessel bow is pointed to the incident waves, whereas the $0^{\circ}$ heading angle denotes that the stern is pointed to the incident waves.

Linear and quadratic viscous damping coefficients are also given in Table 1. In this study, they are represented as the ratios to the critical damping, $2 \sqrt{m c}$, where $m$ denotes the roll moment of inertia and $c$ denotes the roll hydrostatic restoring moment. The added moment of inertia in the critical damping definition in this text is excluded in expressing the viscous damping terms for the sake of simplicity. These terms were previously obtained by the free decay test with the STS mooring configuration [20]. 
YH Kim, DW Jung, HD Song, YU Won, DH Jung
Experimental Study on Coordinated Heading Control of Four Vessels Moored Side by Side

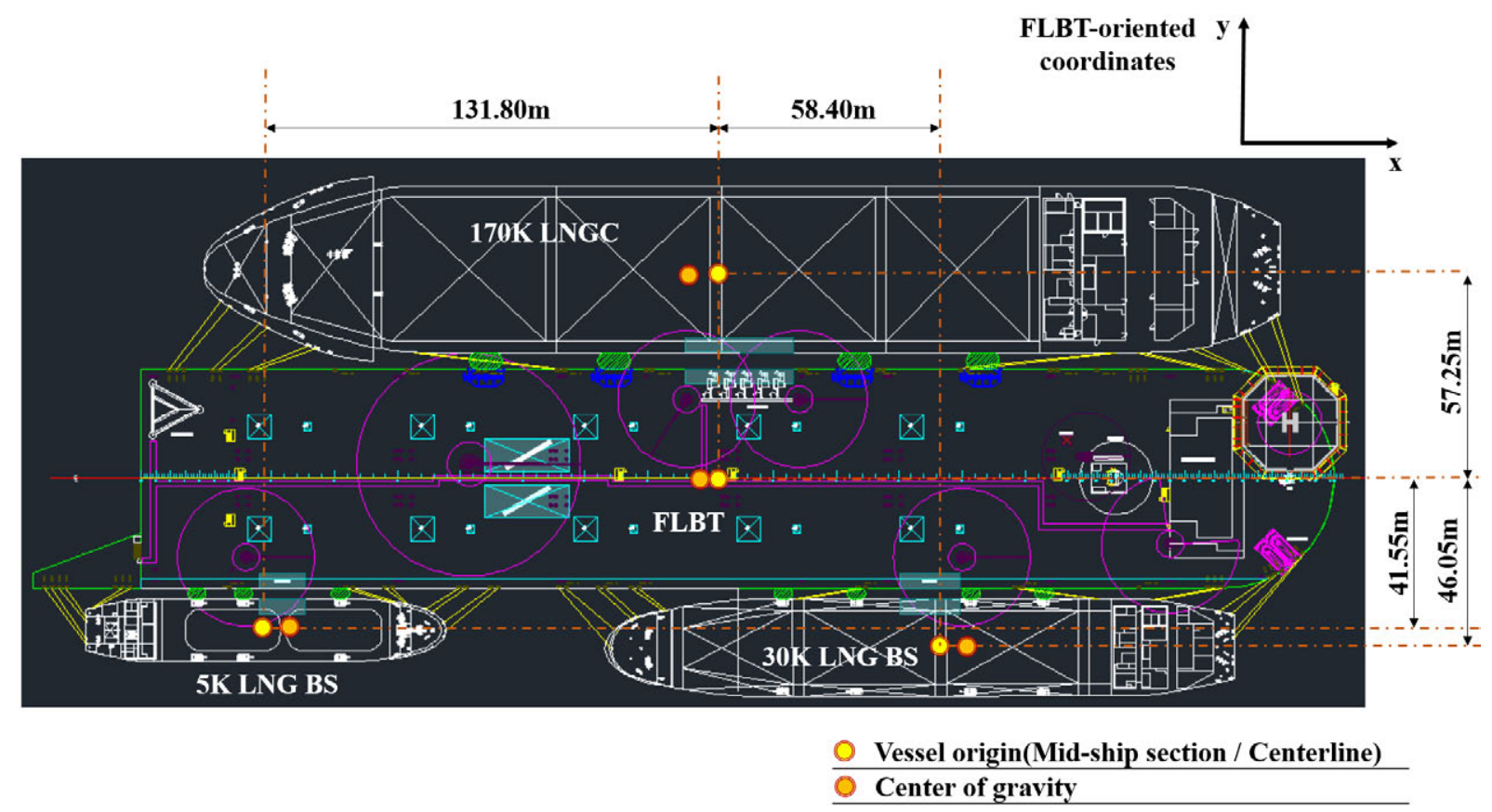

Fig. 1 General arrangement of four vessels in a side-by-side mooring configuration.

Table 1 Main characteristics and locations of four vessels

\begin{tabular}{|c|c|c|c|c|}
\hline & FLBT & LNGC & $30 \mathrm{~K}$ LNGBS & $5 \mathrm{~K}$ LNGBS \\
\hline Length $[\mathrm{m}]$ & 355.6 & 294.0 & 172.0 & 99.0 \\
\hline Breadth [m] & 60.0 & 45.5 & 26.5 & 17.0 \\
\hline Depth [m] & 32.7 & 26.0 & 15.0 & 10.0 \\
\hline Draft $[\mathrm{m}]$ & 13.5 & 12.0 & 5.1 & 4.8 \\
\hline Displacement [ton] & $2.39 \mathrm{e} 05$ & $1.11 \mathrm{e} 05$ & $1.69 \mathrm{e} 04$ & $4.75 \mathrm{e} 03$ \\
\hline Water line area $\left[\mathrm{m}^{2}\right]$ & $1.885 \mathrm{e} 04$ & $1.111 \mathrm{e} 04$ & $3.593 \mathrm{e} 03$ & $1.382 \mathrm{e} 03$ \\
\hline LNG storage capacity $\left[\mathrm{m}^{3}\right]$ & $220 \mathrm{e} 03$ & $170 \mathrm{e} 03$ & $30 \mathrm{e} 03$ & $5 \mathrm{e} 03$ \\
\hline Roll radius of gyration $[\mathrm{m}]$ & 16.26 & 18.78 & 9.81 & 6.51 \\
\hline Pitch radius of gyration $[\mathrm{m}]$ & 87.08 & 65.29 & 43.25 & 24.95 \\
\hline Yaw radius of gyration $[\mathrm{m}]$ & 87.87 & 65.29 & 43.25 & 24.95 \\
\hline Longitudinal centre of gravity [m] & -0.70 & -1.27 & 4.62 & 3.12 \\
\hline Vertical centre of gravity [m] & 3.30 & 4.75 & 2.74 & 0.25 \\
\hline Troll $[\mathrm{sec}]$ & 12.26 & 18.62 & 9.52 & 7.58 \\
\hline Heading $\left[{ }^{\circ}\right]$ & 180.0 & 0.0 & 0.0 & 180.0 \\
\hline Viscous damping (Linear/Quadratic) & $2.01 \% / 0.03 \%$ & $0.60 \% / 0.19 \%$ & $2.00 \% / 0.00 \%$ & $2.00 \% / 0.86 \%$ \\
\hline Location in $\mathrm{x}$-direction $[\mathrm{m}]$ & 0.00 & 0.00 & 58.40 & -131.80 \\
\hline Location in y-direction [m] & 0.00 & 57.25 & -46.05 & -41.55 \\
\hline
\end{tabular}

\subsection{Side-by-side mooring system}

The side-by-side mooring system, which includes mooring ropes and pneumatic fenders, is shown in Fig. 2 along with identifications. The original side-by-side mooring system is composed of 48 mooring ropes and 11 fenders; all the mooring ropes could not be installed in the models as the experimental models were scaled down by a ratio of 1:65. Two adjacent mooring ropes were instead unified as one equivalent spring; hence, 24 mooring ropes and 11 fenders were installed in the experiment. 


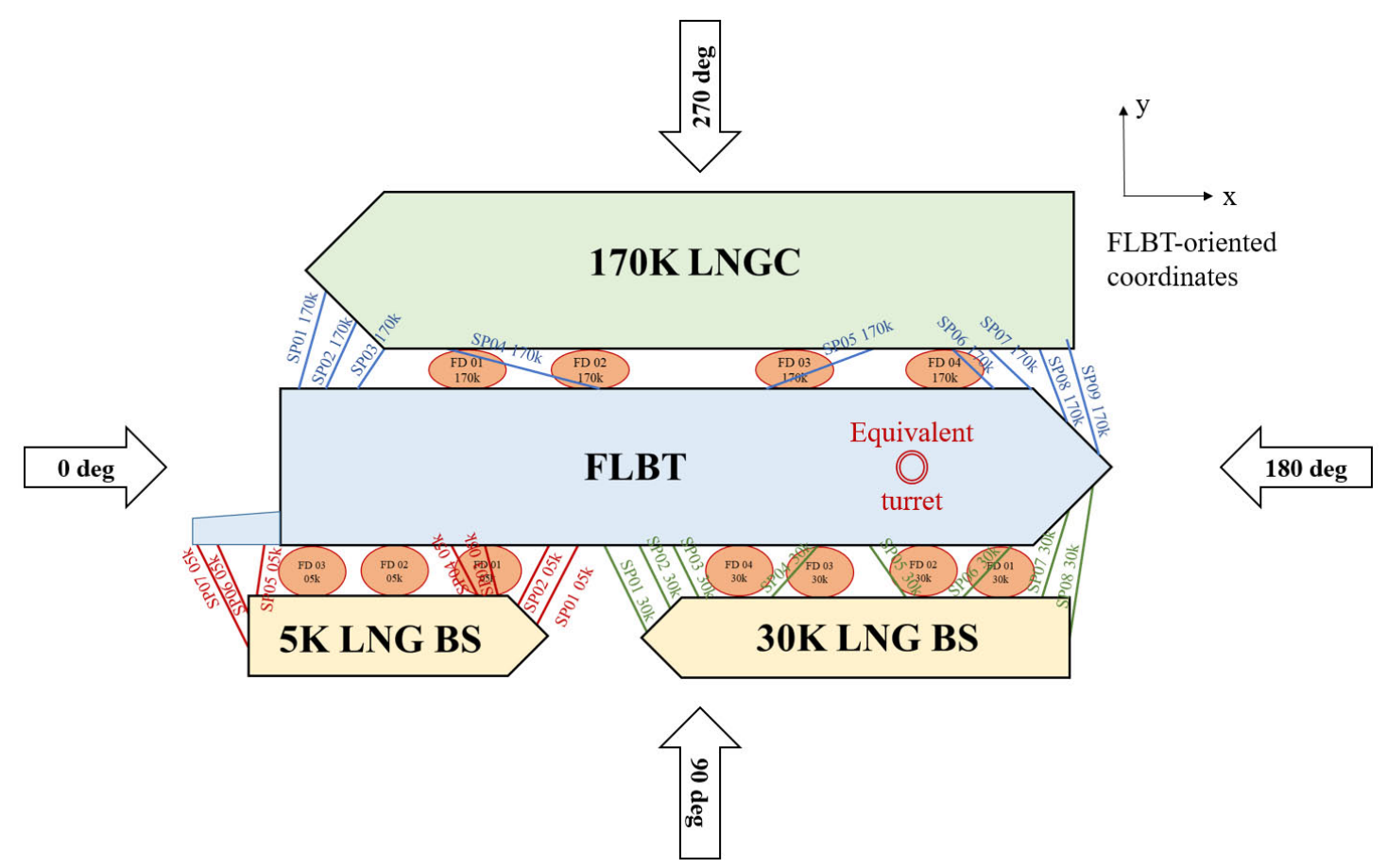

Fig. 2 Arrangements of the experimental side-by-side mooring system (mooring ropes and fenders).

The mooring ropes consist of a tail rope and two end ropes, the specifications of which are shown in Table 2. The maximum length of the tail rope in a line was $22.0 \mathrm{~m}$, and the remaining portion was consistent with the other ropes. The maximum breaking loads, including safety factors, are also listed. Four pneumatic fenders of $4.5 \mathrm{~m}$ in diameter and 7.0 $\mathrm{m}$ in length were installed between the FLBT and the LNGC. Their maximum breaking load (MBL) was $5860 \mathrm{kN}$, and their tension at the original vessel configuration was $351.6 \mathrm{kN}$. Seven pneumatic fenders of $3.0 \mathrm{~m}$ in diameter and $5.0 \mathrm{~m}$ in length were installed between the FLBT and the 30K LNGBS (four fenders), and the FLBT and the 5K LNGBS (three fenders). The latter MBL was $2783.0 \mathrm{kN}$, and its tension at the initial position was $166.98 \mathrm{kN}$. The experimental setup of four vessels with the ship-to-ship mooring configuration is shown in Fig. 3, while the model of mooring ropes and fenders is shown in Fig. 4. The inlet of the mooring rope at the FLBT was formed by two orthogonal smooth rollers to minimise the friction force. The fenders were modelled with a rigid rod and pivot; therefore, the compressive force at the fender installation position can be calculated with the measured tensile load at the opposite end point.

For more detail on the experimental representation of the side-by-side mooring system, see Kim et al. [18].

Table 2 Mooring rope properties

\begin{tabular}{|c|c|c|c|}
\hline \multicolumn{2}{|c|}{ Installed vessels } & Rope & Tail rope \\
\hline FLBT & LNGC & $\begin{array}{c}\text { Wire } 35 \mathrm{~mm} \\
(\text { MBL: } 914.3 \mathrm{kN})\end{array}$ & $\begin{array}{c}\text { Nylon } 80 \mathrm{~mm} \\
(\text { MBL: } 1307.4 \mathrm{kN})\end{array}$ \\
\hline FLBT & 30K LNGBS & $\begin{array}{c}\text { Polypropylene } 75 \mathrm{~mm} \\
(\text { MBL: } 725.9 \mathrm{kN})\end{array}$ & $\begin{array}{c}\text { Nylon } 68 \mathrm{~mm} \\
(\text { MBL: } 961.4 \mathrm{kN})\end{array}$ \\
\hline FLBT & 5K LNGBS & $\begin{array}{c}\text { Polypropylene } 60 \mathrm{~mm} \\
(\text { MBL } 465.0 \mathrm{kN})\end{array}$ & $\begin{array}{c}\text { Nylon } 56 \mathrm{~mm} \\
(\text { MBL: } 682.8 \mathrm{kN})\end{array}$ \\
\hline
\end{tabular}




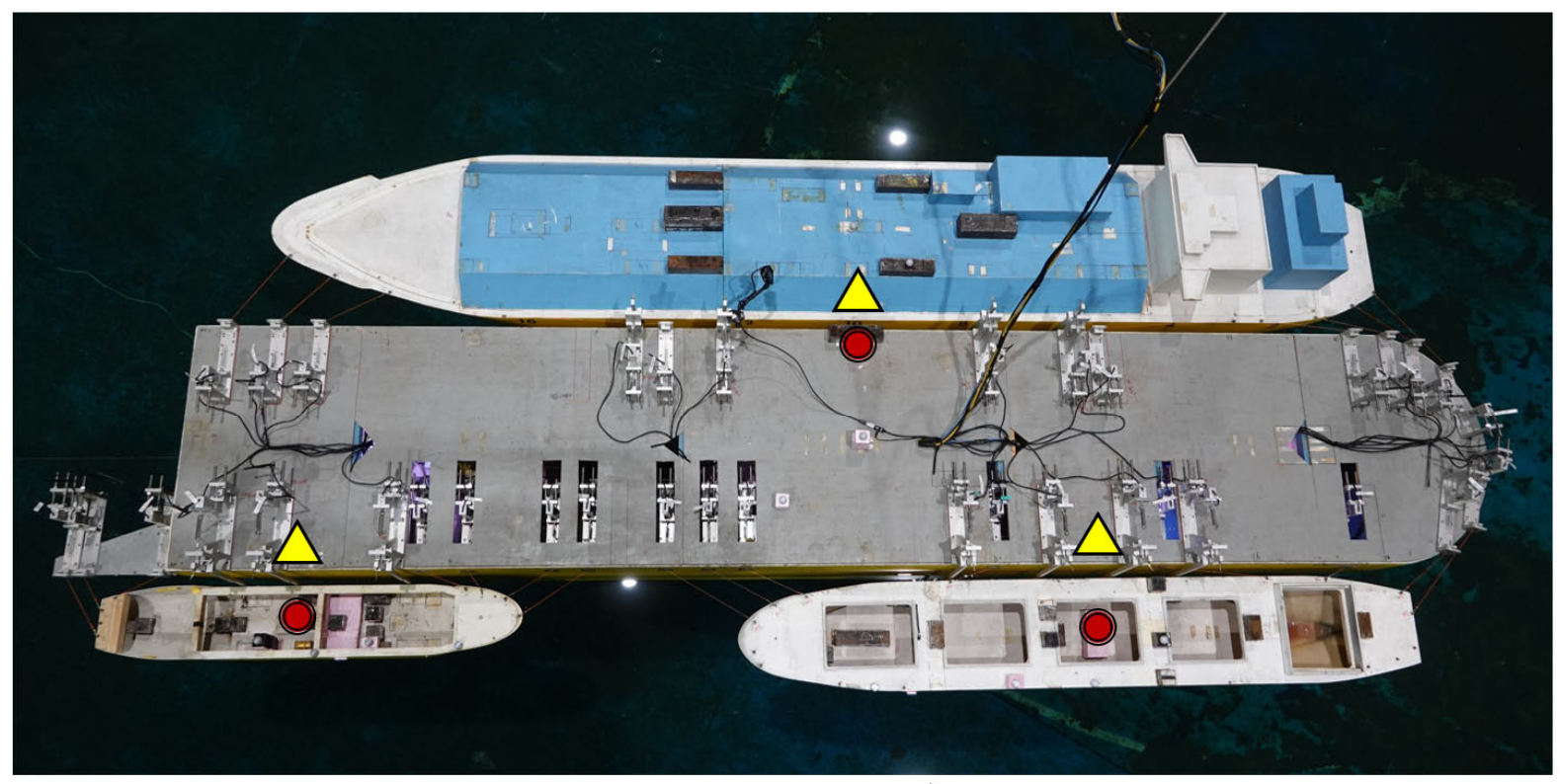

○ : LNG loading arm position

$\triangle:$ Manifold position

Fig. 3 Experimental setup for four vessels in a side-by-side mooring configuration.
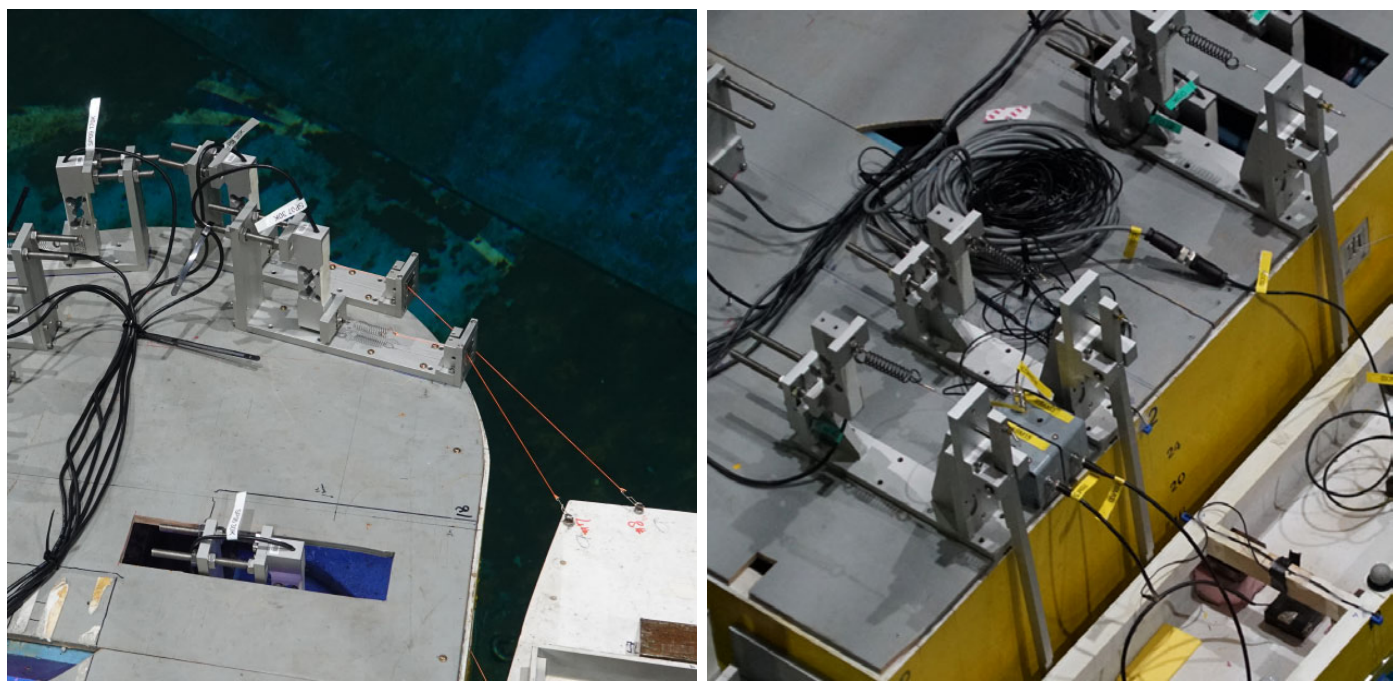

Fig. 4 Experimental model of mooring rope (left) and fender (right)

\subsection{FLBT mooring system}

An FLBT has two station-keeping systems; one consists of an internal turret with catenary mooring lines, and the other consists of bow tunnel thrusters. The turret system allows an FLBT to maintain its position and weather with the minimal environmental load. The catenary mooring lines were modelled with bi-linear springs, thus providing the structure with an adequate restoring force. An FLBT can also control the yaw displacement with stern tunnel thrusters and the internal turret. The schematic representation of the self-mooring FLBT systems and their longitudinal positions are shown in Fig. 5.

The design power capacity for a tunnel thruster is $3,000 \mathrm{~kW}$, which becomes $561 \mathrm{kN}$ with a conversion ratio between power and force of $0.187 \mathrm{~kW} / \mathrm{kN}$. Three tunnel thrusters were designed for installation on the skeg as the total thruster capacity is $1,683 \mathrm{kN}$. Because there was not enough space on the experimental model, we could only install two tunnel thrusters for the experiment. Similar to the side-by-side mooring rope representation, we adjusted the maximum thrust force capacity. 
Figure 6 shows the experimental representation of tunnel thrusters, and Figure 7 the revolutions per second (RPS) versus thrust in the x-direction and the y-direction. The maximum thrust capacity in model scale is $0.625 \mathrm{kgf}$ (with the 1:65 scaling ratio). As shown in Fig. 7, the tunnel thrusters provide the maximum thrust at 46 RPS in the positive yaw direction, while they hardly produce the maximum thrust at 50 RPS in the negative yaw direction. The thrust force in the $\mathrm{x}$-direction from the tunnel thrusters is negligible compared to that in the y-direction. Even though there was a small discrepancy in the total thrust between the positive and negative propulsion directions, they seemed to comparatively represent the design performance.

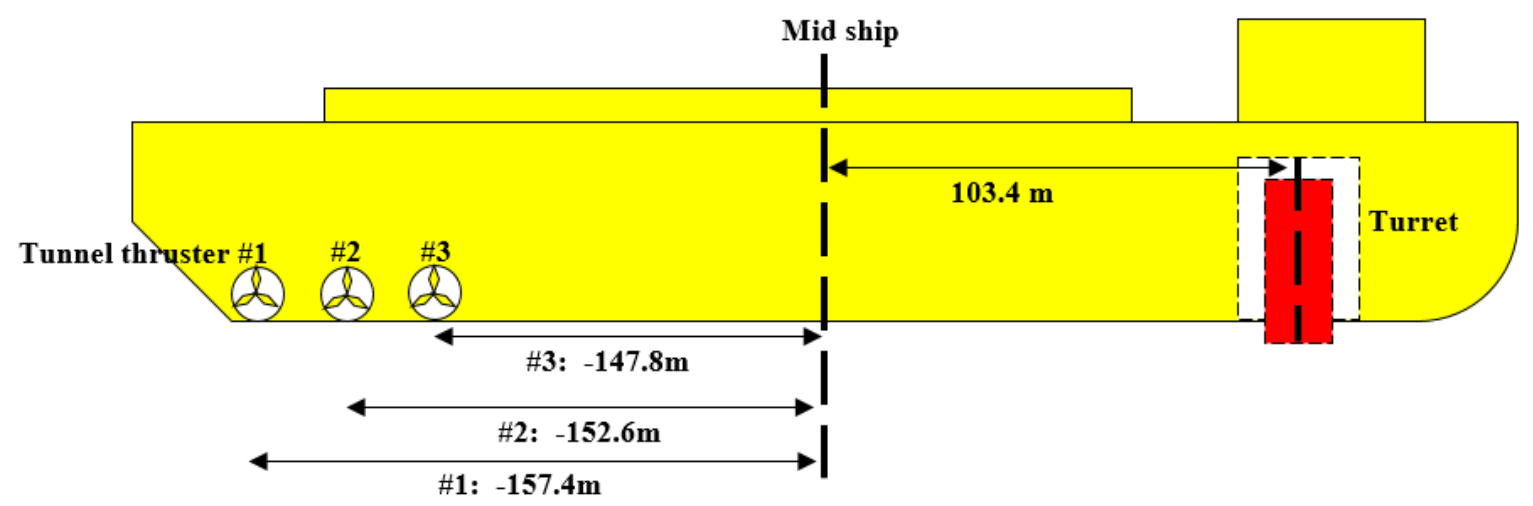

Fig. 5 Schematic representation of the FLBT self-mooring system.
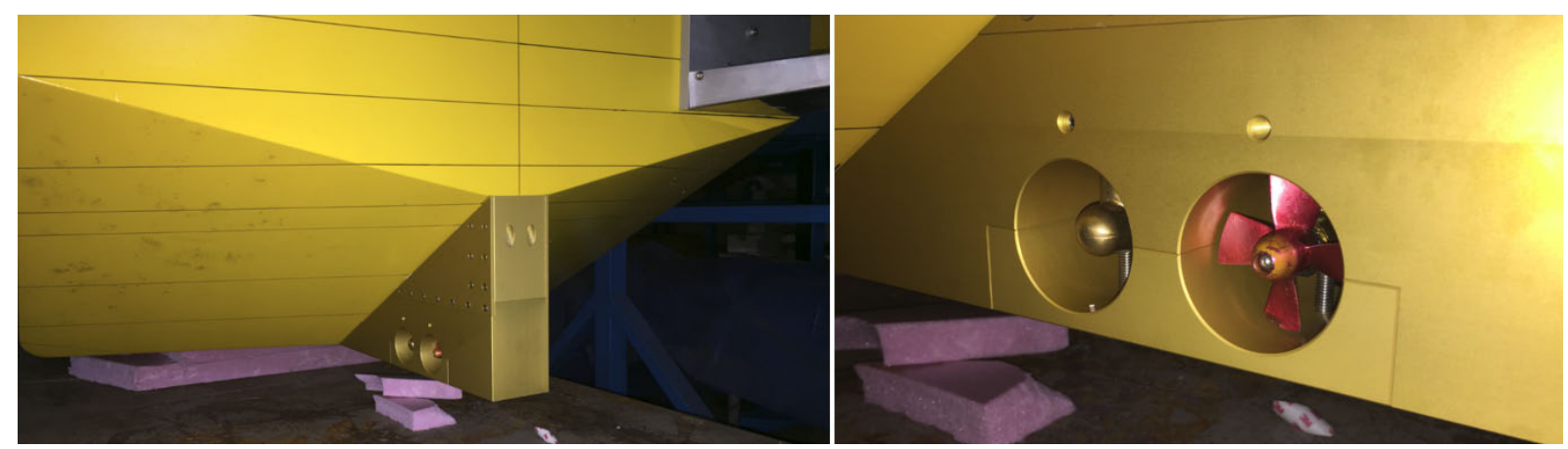

Fig. 6 Experimental representation of tunnel thrusters.

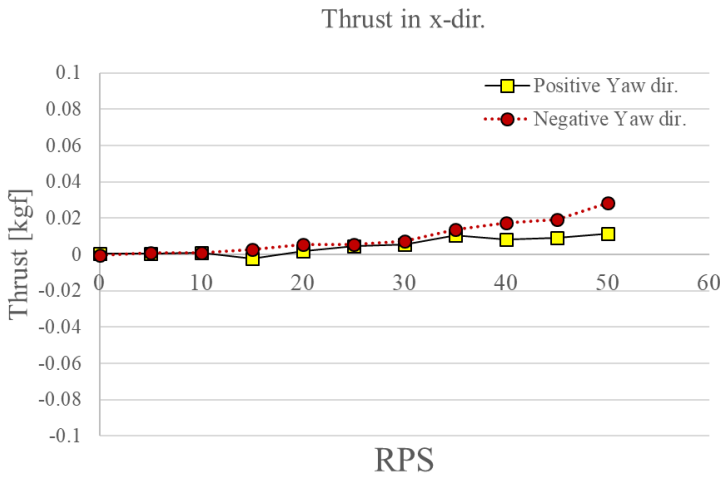

Fig. 7(a) RPS-thrust curve in the x-dir. (in model scale).
Thrust in y-dir.

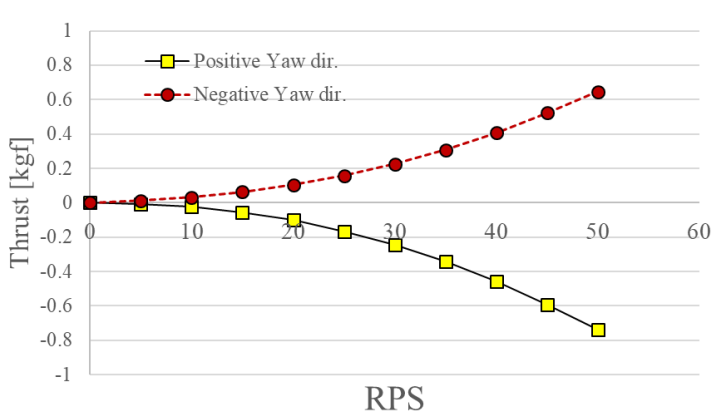

Fig. 7(b) RPS-thrust curve in the y-dir. (in model scale). 
In this study, a conventional proportional-differential control algorithm was used and two different gains were adopted in separating the discrepancy zones. The low discrepancy zone was set to less than $5^{\circ}$, and the high discrepancy zone was set to more than $10^{\circ}$. A constant PD gain was applied in each zone, as shown in Table 3, while the PD gain was linearly interpolated in the intermediate zone. A detailed control algorithm and explanations can be found in [16] and [17].

Table 3 Control gains for the FLBT heading control

\begin{tabular}{|c|c|c|c|}
\hline \multicolumn{2}{|c|}{ Error $\left[{ }^{\circ}\right]$} & $K_{P}[\mathrm{Nm} / \mathrm{deg}]$ & $K_{D}[\mathrm{Nm} \cdot \mathrm{s} / \mathrm{deg}]$ \\
\hline- & 0.0 & 0.00 & 0.00 \\
\hline Low & 5.0 & 0.19 & 5.51 \\
\hline High & 10.0 & 0.43 & 8.26 \\
\hline
\end{tabular}

\subsection{Environmental and heading control conditions}

In this study, a white noise wave condition and four combined environments with irregular waves and current conditions were considered; they are all listed in Table 4. The environmental conditions were obtained by numerical simulations (SWAN, developed by Delft University) with the real marine environment measurement data near Pusan Port. The irregular waves were modelled as a Joint North Sea Wave Project (JONSWAP) spectrum and had a one-year return period with or without hurricane history data. Curiously, the wave conditions with the hurricane data were less harsh than those without the data because we only focused on the one-year return period condition. For all combined conditions, the current with a one-year return period was generated for the head sea.

Although the wind should have been considered in the experiments, our facility could not generate the uniform wind field for all vessels. Also, the experimental representations of mooring ropes and fenders significantly destroyed the topside configuration. Due to the complexity of the topside experimental setup and the difficulty in generating the uniform wind field for all vessels, wind loads were excluded in this paper.

The duration of a white noise test (WNT01) was 1 hour, and that of design operational environment tests (DOENV01-04) was 3 hours in real scale. Considering the Froude scaling law, the time of the former test was $447 \mathrm{sec}$ and that of the latter was $1340 \mathrm{sec}$. The sampling rate of the measured quantities was $100 \mathrm{~Hz}$.

Table 4 Main characteristics and locations of four vessels

\begin{tabular}{|c|c|c|c|c|c|c|c|}
\hline \multirow[b]{2}{*}{$\begin{array}{l}\text { Environment } \\
\text { ID }\end{array}$} & \multicolumn{2}{|c|}{ Current } & \multicolumn{4}{|c|}{ Wave } & \multirow[b]{2}{*}{ Remarks } \\
\hline & $\begin{array}{c}\mathrm{Vc} \\
{[\mathrm{m} / \mathrm{s}]}\end{array}$ & $\begin{array}{c}\text { Heading } \\
{\left[^{\circ}\right]}\end{array}$ & $\begin{array}{l}\mathrm{Hs} \\
{[\mathrm{m}]}\end{array}$ & $\begin{array}{l}\mathrm{Tp} \\
{[\mathrm{s}]}\end{array}$ & $\begin{array}{l}\gamma \\
{[-]}\end{array}$ & $\begin{array}{c}\text { Heading } \\
{\left[^{\circ}\right]}\end{array}$ & \\
\hline WNT01 & - & - & 2.0 & $5-20$ & - & 180.0 & White noise case \\
\hline DOENV01 & 1.23 & 180.0 & 1.54 & 10.0 & 3.3 & 202.5 & $\begin{array}{c}\text { Without hurricane } \\
\text { Non-collinear condition }\end{array}$ \\
\hline DOENV02 & 1.23 & 180.0 & 1.98 & 8.5 & 3.3 & 180.0 & $\begin{array}{l}\text { Without hurricane } \\
\text { Collinear condition }\end{array}$ \\
\hline DOENV03 & 1.23 & 180.0 & 1.22 & 10.0 & 3.3 & 247.5 & $\begin{array}{c}\text { With hurricane } \\
\text { Non-collinear condition }\end{array}$ \\
\hline DOENV04 & 1.23 & 180.0 & 1.45 & 8.5 & 3.3 & 180.0 & $\begin{array}{c}\text { With hurricane } \\
\text { Collinear condition }\end{array}$ \\
\hline
\end{tabular}


We measured the current load acting on the FLBT with the side-by-side mooring configuration and compared it with the previous experimental data for a one-body case, as shown in Fig. 8. All current loads in this figure are divided by the square of the current velocity. The yellow squares with a black outline are the present data. The current loads in the $\mathrm{y}$-direction are similar and are in the $150-210^{\circ}$ range, whereas those in the x-direction are smaller than those noted in one-body experimental data. We cautiously surmised that the narrow gaps between the FLBT and the other vessels interrupted the current flow, which led to the weak $\mathrm{x}$-direction force acting on the FLBT. For a more precise analysis of this phenomenon, other research methodologies must be implemented, such as computational fluid dynamics.

\section{Current Load Tests [Fx]}

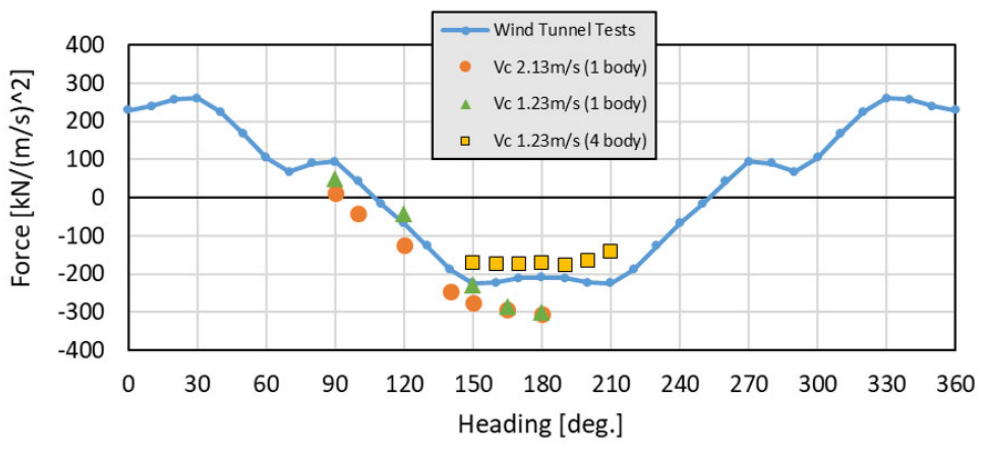

Current Load Tests [Fy]

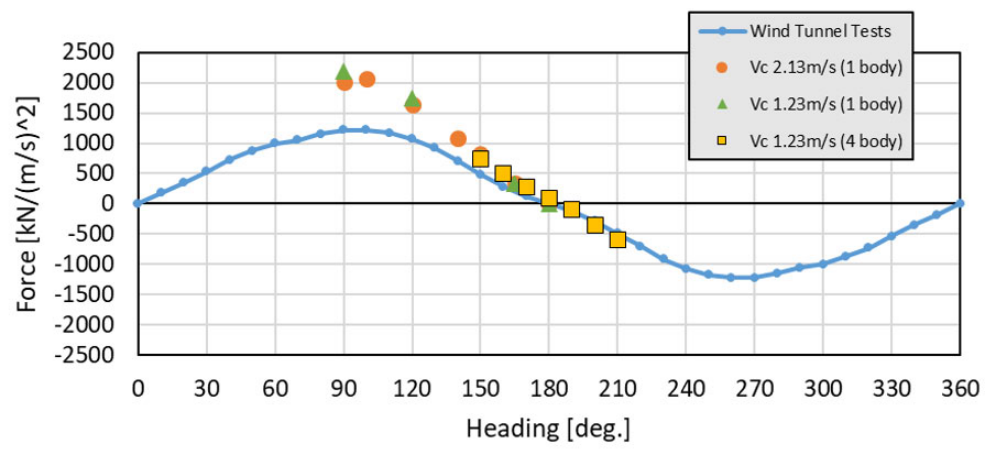

Fig. 8 Current load acting on the FLBT in the x-direction (above) and the y-direction (below).

We controlled the FLBT heading angle with stern tunnel thrusters. Firstly, we turned off the tunnel thrusters, and then we changed the FLBT yaw heading from $+10^{\circ}$ to $-30^{\circ}$. The positive control heading was subject to the LNGC shielding zone, while the negative control heading was intended for the two LNGBS shielding zones. According to the previous study without heading control, two small LNGBSs were more hazardous in the LNG bunkering process [19]. Hence, we perceived the need to conduct more experiments under the negative heading control conditions, which may increase the safety of the LNG bunkering process of two LNGBSs. All control headings are written as differences from the initial arrangement $\left(180^{\circ}\right.$ heading of FLBT). Table 5 shows the experiment test IDs, their environments and heading control conditions. 
YH Kim, DW Jung, HD Song, YU Won, DH Jung
Experimental Study on Coordinated Heading Control of Four Vessels Moored Side by Side

Table 5 Experiment test IDs and their descriptions

\begin{tabular}{cccc} 
Test ID & Environment ID & $\begin{array}{c}\text { Heading control } \\
\text { condition }\end{array}$ & Remarks \\
\hline 1101 & WNT01 & - & \\
\hline 1201 & DOENV01 & - & \\
1202 & DOENV02 & - & \\
1203 & DOENV03 & - & weakly shielding the LNGC \\
1204 & DOENV04 & - & weakly shielding two LNGBSs \\
\hline 1302 & DOENV01 & +10 deg control & intermediately shielding two LNGBSs \\
1304 & DOENV01 & -10 deg control & strongly shielding two LNGBSs \\
1306 & DOENV01 & -20 deg control & weakly shielding the LNGC \\
1308 & DOENV01 & -30 deg control & weakly shielding two LNGBSs \\
\hline 1402 & DOENV02 & +10 deg control & intermediately shielding two LNGBSs \\
1404 & DOENV02 & -10 deg control & strongly shielding two LNGBSs \\
1406 & DOENV02 & -20 deg control & weakly shielding the LNGC \\
1408 & DOENV02 & -30deg control & weakly shielding two LNGBSs \\
\hline 1502 & DOENV03 & +10 deg control & intermediately shielding two LNGBSs \\
1504 & DOENV03 & -10 deg control & strongly shielding two LNGBSs \\
1506 & DOENV03 & -20 deg control & weakly shielding the LNGC \\
1508 & DOENV03 & -30 deg control & weakly shielding two LNGBSs \\
\hline 1602 & DOENV04 & +10deg control & intermediately shielding two LNGBSs \\
1604 & DOENV04 & -10 deg control & strongly shielding two LNGBSs \\
1606 & DOENV04 & -20 deg control & \\
1608 & DOENV04 & -30 deg control & \\
\hline & & &
\end{tabular}

Two capacitance wave probes were installed at the front and the side of the vessels to observe the quality of incident waves. Non-contact optical cameras with passive markers (QUALISYS) were used in measuring the six degrees of freedom (6-DOF) motions of the four vessels. Optical motion measurement system cameras were installed approximately $5.0 \mathrm{~m}$ back from, and $+10.0 \mathrm{~m}$ above the models. As the appropriate measuring volume for QUALISYS is $10 \mathrm{~m} \times 10 \mathrm{~m} \times 10 \mathrm{~m},+8.0 \mathrm{~m}$ away from markers, this motion measuring setup performed quite well in all experimental test cases. This system can measure rectilinear motions within $10^{-3} \mathrm{~mm}$, and the rotational motions within $10^{-3}$ degrees. Loads on mooring ropes and fenders were measured by a one-axis load cell with a capacitance of $10 \mathrm{kgf}$ in the model scale. The rotations of tunnel thrusters were automatically counted, and the measured quantities were converted in terms of the thrust force based on the relation shown in Fig. 7.

\section{Validation Test}

The white noise wave test was first performed to determine/discern the motion and structural load characteristics of the four vessels in the side-by-side mooring system. Numerical simulations were also conducted using the commercial software AQWA, the submodule of ANSYS. Hydrodynamic coefficients, such as added mass, wave damping, wave excitation force, and wave drift force, were applied as in [19]. In order to suppress the excessive gap flow effect in the numerical calculation, the artificial damping coefficient $(\varepsilon)$ of 0.02 was applied to the free surface boundary condition in the boundary element method. Drift force comparisons were formerly performed in order to find a suitable artificial damping coefficient. More details on the numerical scheme and the coefficient matching theory are presented in [18]. 
Figure 9 shows the motion responses of the four vessels in the WNT01 condition, represented in terms of Response Amplitude Operator (RAO). The measured motion responses in the time domain were converted to the frequency domain, called 'motion response spectrum', with the Fast Fourier Transform (FFT). The RAOs were determined as the root square of the motion response spectrum divided by the wave spectrum, which is written in Eq. (1). Since the second order motions were identified previously as not significant for evaluating the operational safety of the STS mooring system [18], the first order responses induced by incident wave components $(0.4 \mathrm{rad} / \mathrm{s} \sim 1.4 \mathrm{rad} / \mathrm{s})$ were only compared in the validation test in terms of RAO.

Motion Response Spectrum $=\mid$ Response Amplitude Operator(RAO) $\left.\right|^{2} \times$ Wave Spectrum

Response Amplitude Operator(RAO) $=\sqrt{\frac{\text { Motion Response Spectrum }}{\text { Wave Spectrum }}}$

The 6-DOF motions of both the experimental and numerical results are included. The solid lines indicate the numerical results, and the dotted lines represent the experimental data. The colours are used to represent the vessels: red represents the FLBT, green represents the LNGC, blue represents the $30 \mathrm{~K}$ LNGBS, and black represents the 5K LNGBS.

The FLBT and LNGC numerical and experimental data are in agreement for all motion modes. It seems that narrow gap flows rarely affect the motions of the FLBT and the LNGC as their displacements are considerably larger than those of two LNGBSs. The numerical results of the $30 \mathrm{~K}$ LNGBS are slightly exaggerated compared to those of the experimental data, especially in the low frequency range (below $0.6 \mathrm{rad} / \mathrm{s}$ ). The discrepancies in the methodology results are significant for the $5 \mathrm{~K}$ LNGBS. In the numerical results, there is a peak for the surge motion which is not found in the experimental data, while sway motion is observed in the high frequency range of experimental data. These small amounts are also found in the roll motion, where they are distributed among all the frequency ranges. The resonant yaw motion frequencies are also different.

We then reviewed the time series of horizontal motions (surge, sway, and yaw) of the $5 \mathrm{~K}$ LNGBS, as shown in Fig. 10. The slowly varying response in surge motion is more significant in the numerical results, and the first-order motions in the surge and sway modes are relatively more pronounced in the experimental data. For the yaw motion, both the numerical and experimental results display a similar tendency. As for the time series, we could not find a clear reason for the differences in the frequency domain. We carefully infer that the boundary element method, a fundamental theory of the commercial code, hardly estimated the effectiveness of the diffraction of incident waves due to the $30 \mathrm{~K}$ LNGBS. Although the gap flow modelling by the boundary element method has been studied previously [8,11], no single solution has been reached. The displacement of the $5 \mathrm{~K}$ LNGBS is the smallest, and there are significant wave diffractions by the FLBT and 30K LNGBS, implying that the $5 \mathrm{~K}$ LNGBS is vulnerable to narrow gap flows. 
YH Kim, DW Jung, HD Song, YU Won, DH Jung

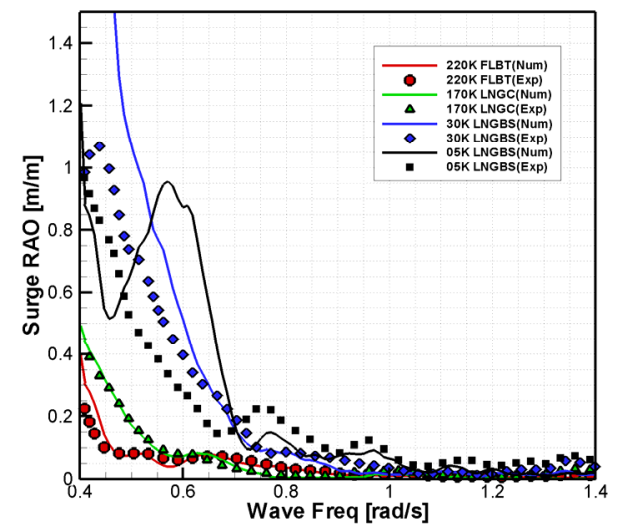

(a) Surge motion RAO.

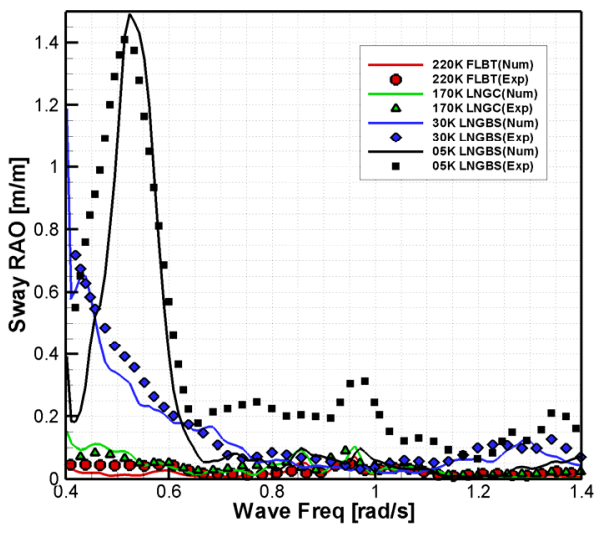

(b) Sway motion RAO.

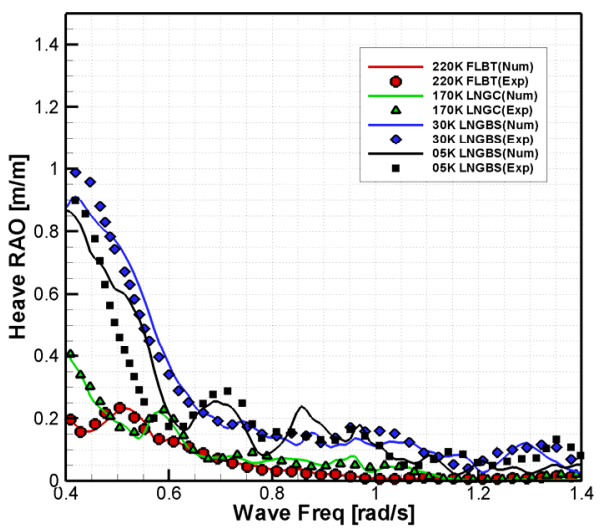

(c) Heave motion RAO.
Experimental Study on Coordinated Heading Control of Four Vessels Moored Side by Side

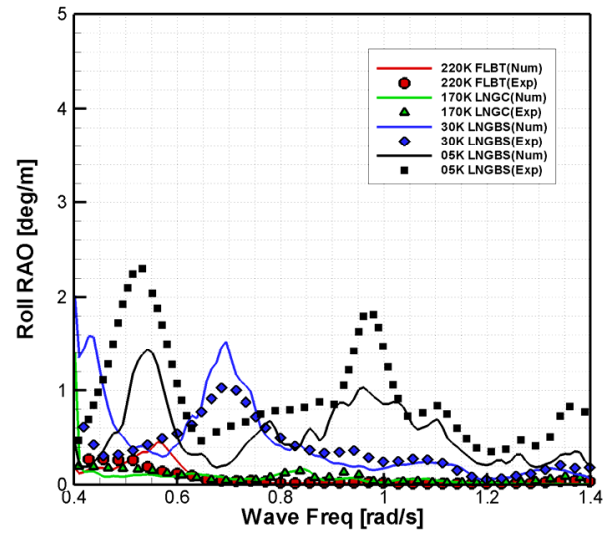

(d) Roll motion RAO.

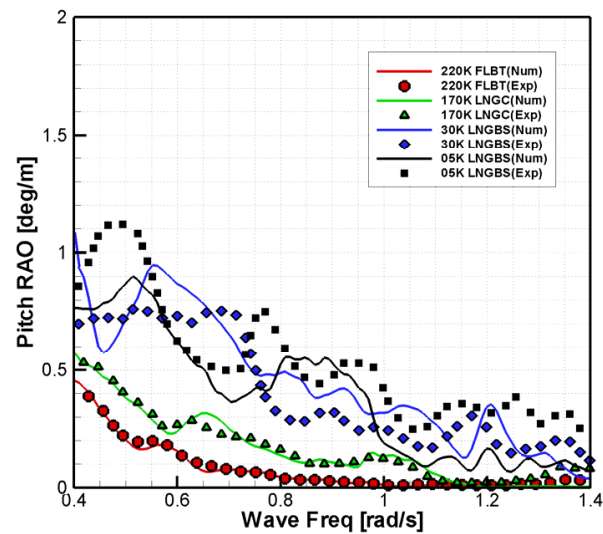

(e) Pitch motion RAO.

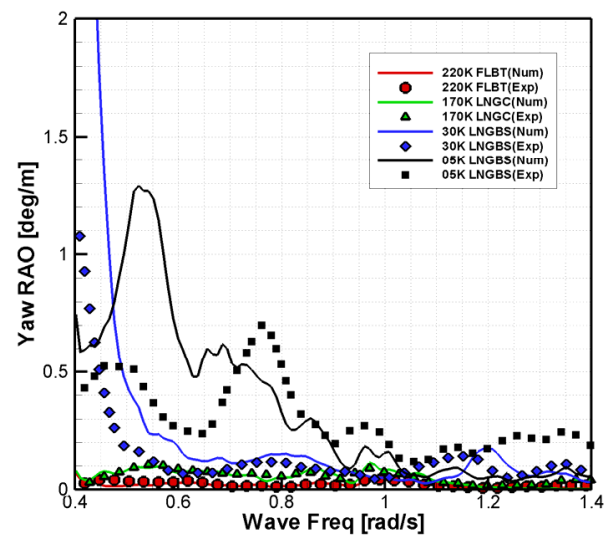

(f) Yaw motion RAO.

Fig. 9 Motion spectrum responses in white noise waves $\left(\theta=180^{\circ}\right)$. 

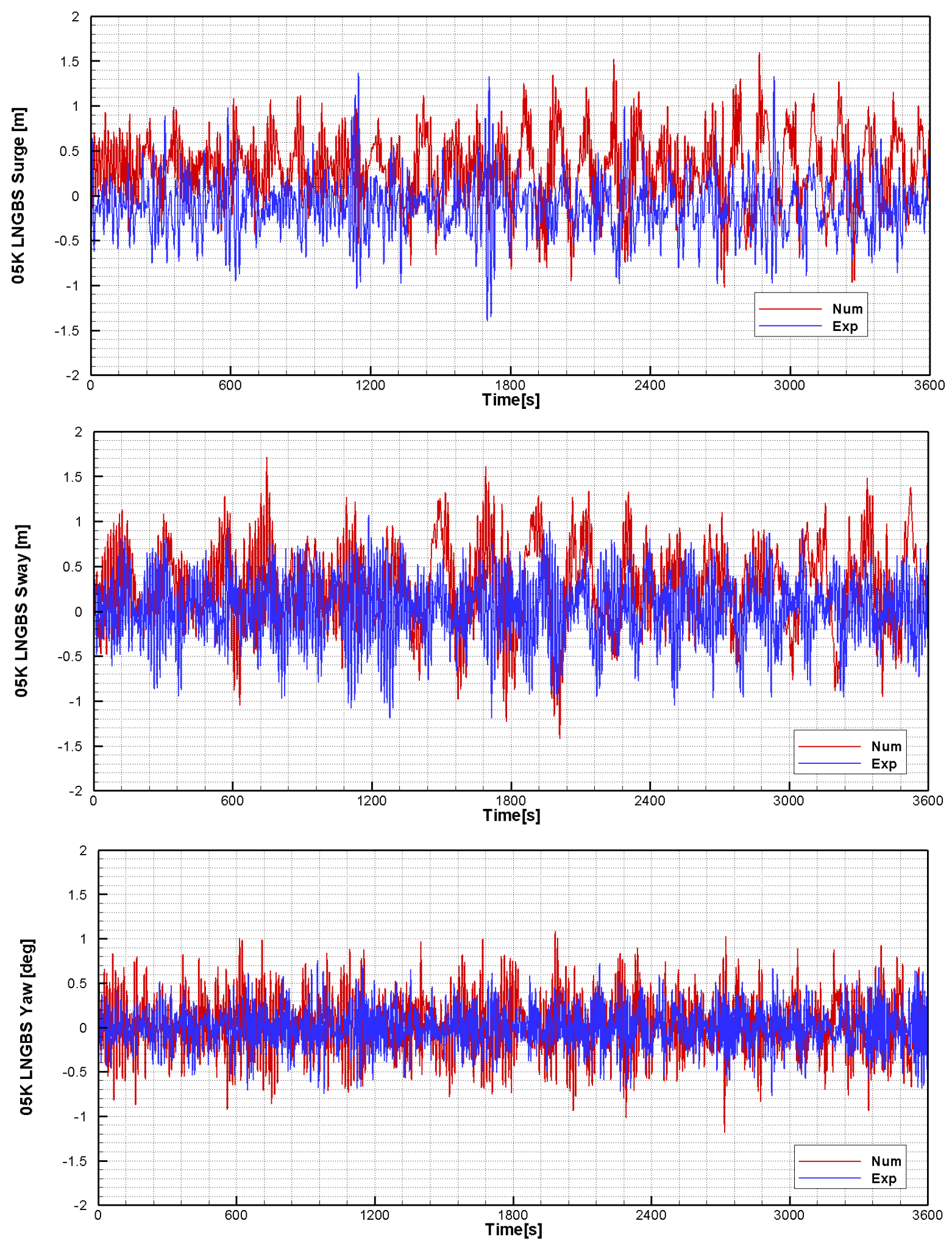

Fig. 10 Time series of 5K LNGBS horizontal motion modes in the white noise test.

Tension forces acting on the mooring ropes between the FLBT and the LNGC, and the FLBT and the 5K LNGBS are shown as tension RAOs in Fig. 11. For the case of FLBT and LNGC, although some mooring rope tension forces (MR07, 08) are exaggerated in the numerical results, both results are in agreement. Similar to the motion responses, significant differences are shown between the FLBT and the 5K LNGBS mooring ropes. Resonant behaviours are found in the $5 \mathrm{~K}$ LNGBS bow side mooring ropes (5K MR01-04) in the 
numerical simulations, while no remarkable peak was found in the experiments. Tension forces in the 5K LNGBS stern side mooring ropes (5K MR05-07) are larger in the low frequency range compared to those of the experimental data. Generally, tension forces are over-estimated in the numerical calculations.

Both the motion responses of the four vessels and the calculated tension forces in mooring ropes are greater in the numerical simulations for the $5 \mathrm{~K}$ LNGBS, while those of the other vessels are roughly similar to the experimental data results. Taking into account the inherent limitations of the numerical methodology, effort must be made to minimise the discrepancies. Based on the comparisons between the numerical and experimental results, we concluded that our experimental setup was reliable enough to evaluate the motion characteristics of vessels and the structural behaviours of side-by-side mooring ropes and fenders.

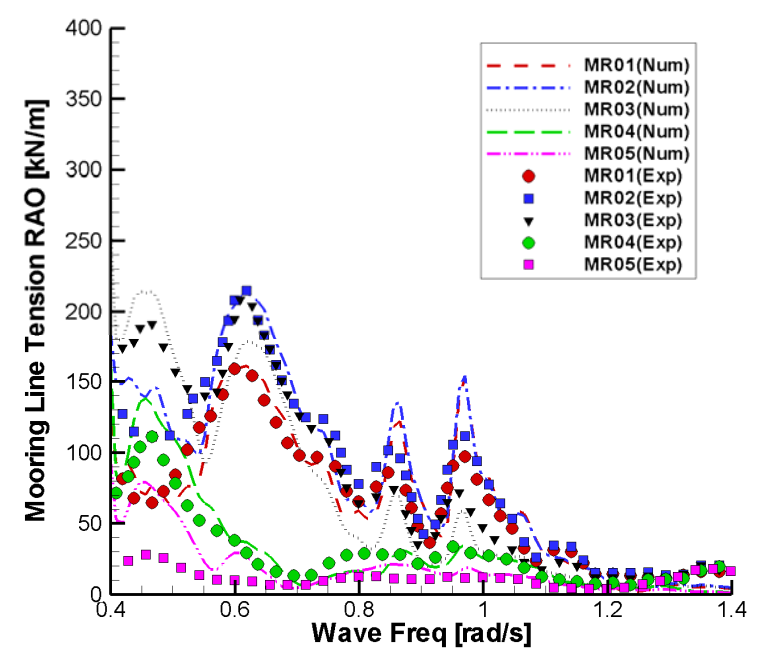

(a) MR01-05 between FLBT and LNGC.

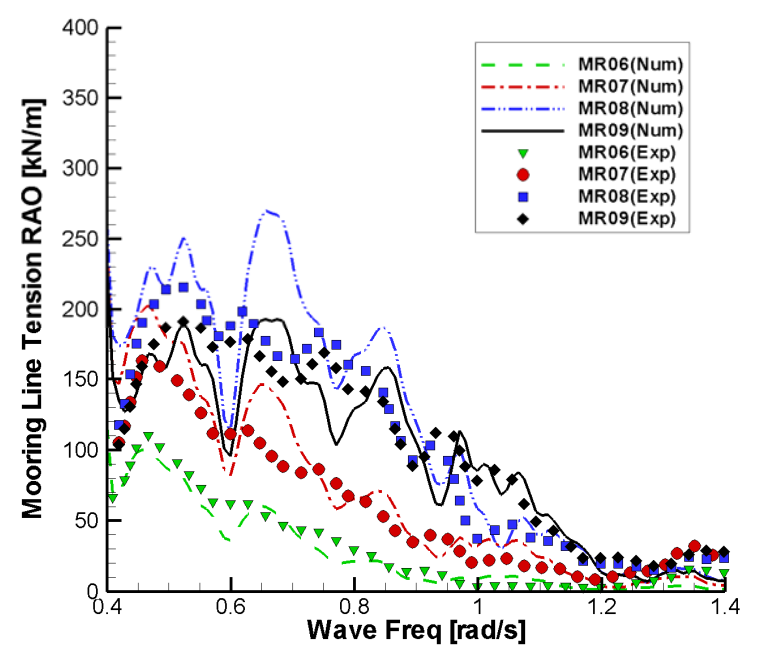

(b) MR06-09 between FLBT and LNGC

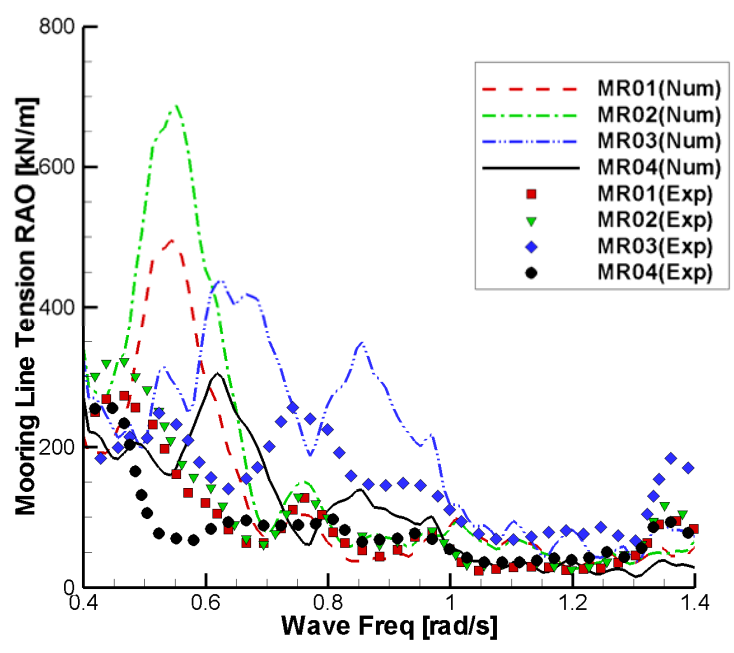

(c) MR01-04 between FLBT and 5K LNGBS.

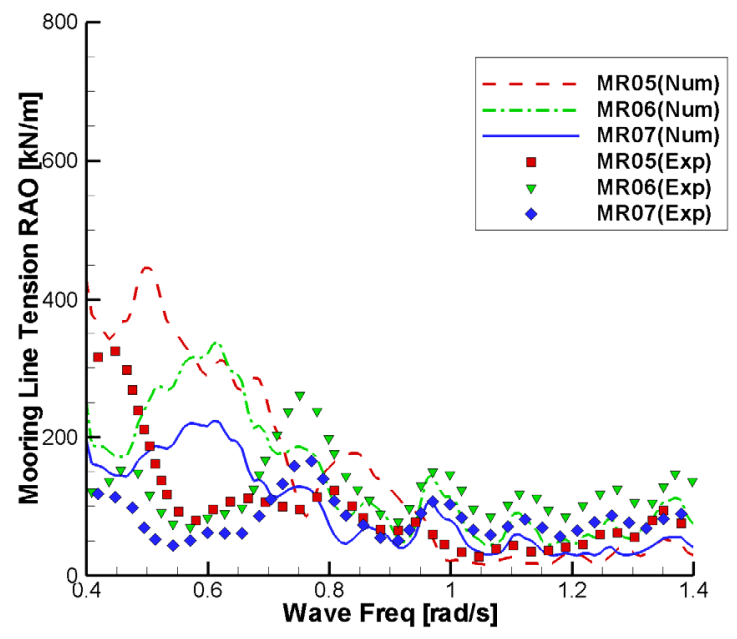

(d) MR05-07 between FLB and T5K LNGBS

Fig. 11 Comparison between the numerical and experimental results of motion responses in the frequency domain.

\section{Experimental Results Heading control performance and post process methodology}

4.1 Heading control performance and post process methodology

Five different heading control conditions (None, $+10^{\circ},-10^{\circ},-20^{\circ}$, and $-30^{\circ}$ ) were considered with four design operational environments (DOENV) which are listed in Table 4. 
Figure 12 shows the total thrust force produced by the stern tunnel thrusters in DOENV01. The wire and hardened springs were installed at the bow and the stern of the FLBT, two for each position with a $60^{\circ}$ between angle, and one-axis load cells were located at the ends of the springs. The RPSs of the two thrusters were measured and converted to force based on the relation in Fig. 7. The thrust force is small in the $+10^{\circ}$ condition, while the force continuously increases from the $-10^{\circ}$ to the $-30^{\circ}$ conditions. The maximum forces in the negative heading control conditions of $-10^{\circ},-20^{\circ}$, and $-30^{\circ}$ are $312 \mathrm{kN}, 1218 \mathrm{kN}$, and $-1485 \mathrm{kN}$, respectively. As the designed maximum capacity of the heading control system of the FLBT is $1683 \mathrm{kN}$, we can confirm that this system can control the FLBT heading from $+10^{\circ}$ to $-30^{\circ}$ in a side-by-side mooring configuration, and the safety margin in the $-30^{\circ}$ condition is extremely small.

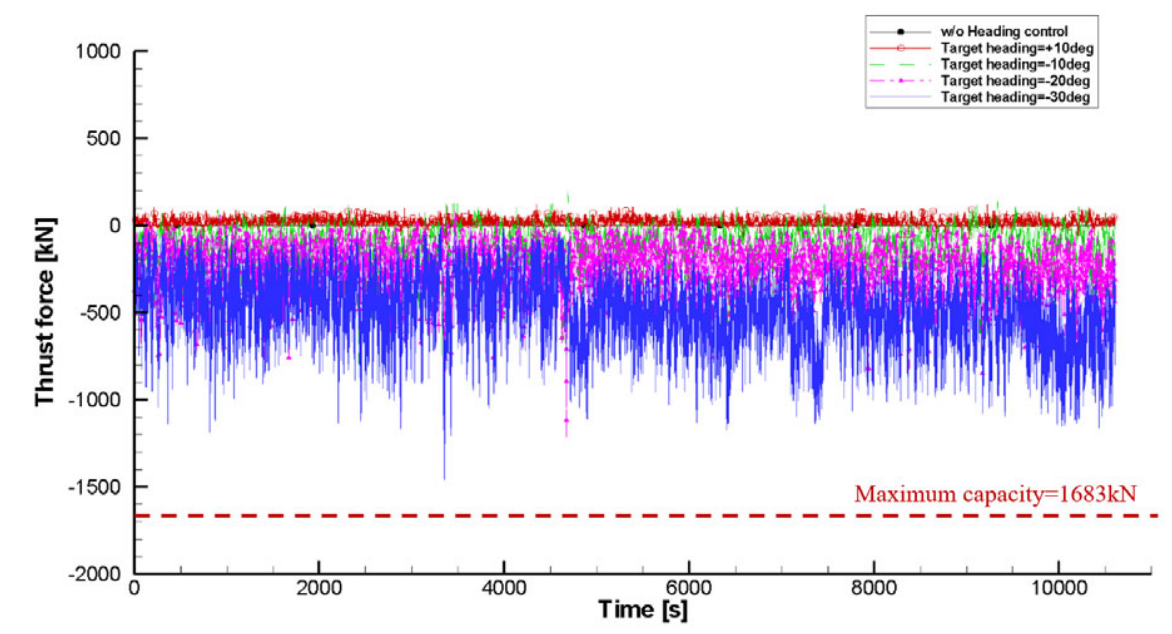

Fig. 12 Total thrust force in the DOENV01 condition for various heading control cases.

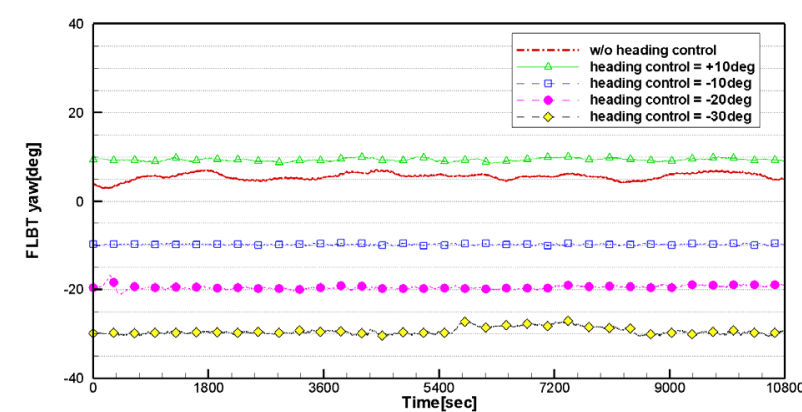

(a) FLBT yaw displacement.

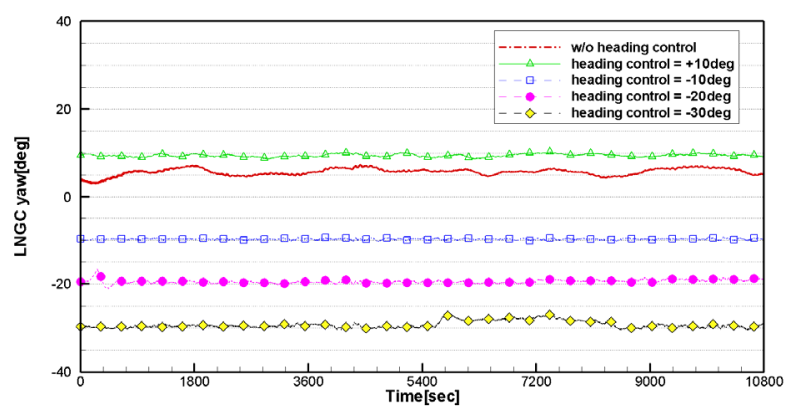

(b) LNGC yaw displacement.

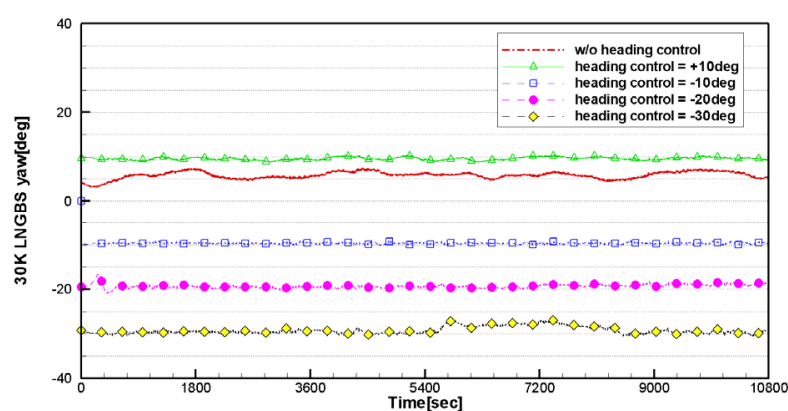

(c) 30K LNGBS yaw displacement.

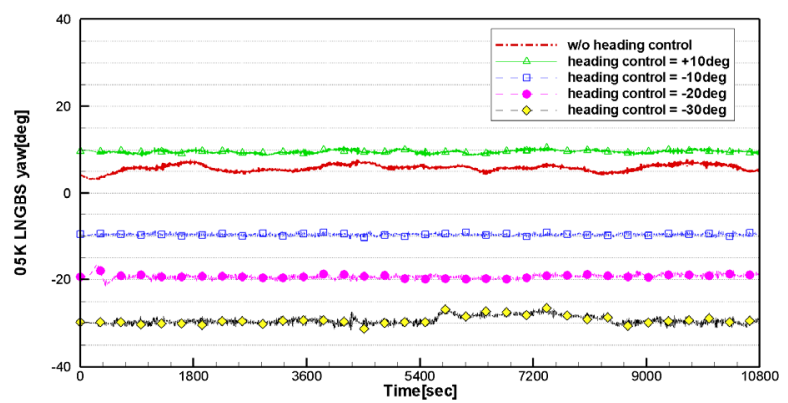

(d) 5K LNGBS yaw displacement.

Fig. 13 Yaw motions of four vessels under the DOENV01 condition with various heading control cases. 
The yaw motions of four vessels in the DOENV01 condition with different heading control conditions are shown in Fig. 13. The dash-dot line represents the results without heading control, and the lines with the triangular, square, circle, and diamond marks represent the results for $+10^{\circ},-10^{\circ},-20^{\circ}$, and $-30^{\circ}$, respectively. The mean yaw equilibrium position without heading control is approximately $+7^{\circ}$, which is close to the +10 heading control condition. As the two headings are extremely close, the measured thrust force barely existed in the $+10^{\circ}$ control condition, as shown in Fig. 12. All other vessels have nearly identical yaw headings for the controlled FLBT yaw heading as there are numerous side-by-side mooring ropes and fenders.

In model experiments, uncertainties, such as electronic biases, mechanical vibrations, repeatability of wave or current generators, and human errors, can affect the measurements. Therefore, we cannot guarantee that the maxima from the measured time series data are robust and exact. Instead, we calculated probabilistic maxima with the extreme value distribution fitting in order to reduce the uncertainty of model tests and increase the reliability of evaluation. There are several extreme value distributions, such as the Weibull distribution, the Gumbel distribution, and the Generalized Extreme Value (GEV) distribution. The Weibull distribution is commonly utilized in extreme value probability analysis because the characteristics of responses are not specified. Since the identification of the most appropriate distribution is not the main issue in this paper, we just adopted the three-parameter Weibull distribution fitting.

The PDF of the three-parameter Weibull distribution for data $x$ is written in Eq. (2).

$$
\begin{aligned}
& f(x)=\frac{\gamma}{\beta}\left(\frac{x-\delta}{\beta}\right) e^{\left[-\left(\frac{x-\delta}{\beta}\right)^{\gamma}\right]} \\
& \text { for } x \geq \delta, \quad f(x ; \delta, \beta, \gamma)>0, \\
& \text { for } \quad x<\delta, \quad f(x ; \delta, \beta, \gamma)=0
\end{aligned}
$$

where $\gamma$ is the shape parameter, $\beta$ is the scale parameter, and $\delta$ is the location parameter. The parameters are calculated from the moment balancing the Weibull distribution in terms of mean, variance, and skewness, and the PDF of the extreme value distribution is formulated as Eq. (3), where $N$ denotes the sampling number of peaks.

$$
\frac{d}{d x}\left\{F^{N}\right\}=N \cdot\left(1-e^{-\left(\frac{x-\delta}{\beta}\right)^{\gamma}}\right)^{N-1} \cdot \frac{\gamma}{\beta} \cdot e^{-\left(\frac{x-\delta}{\beta}\right)^{\gamma}} \cdot-\left(\frac{x-\delta}{\beta}\right)^{\gamma-1}
$$

We can draw the maximum distribution as Eq. (3); exceeding the $\xi \%$ of the area in this function is referred to as the $\xi \%$ fractile extreme value. In this study, 3-hour experiments were performed, while the duration of the LNG bunkering between FLBT and 30K LNGBS is 20 hours (the longest LNG bunkering operation). With a safety factor of 3.0 for operational time, we need to evaluate conservatively the LNG bunkering operational safety for 60 hours. The $95 \%$ fractile value in the Weibull fitting practically implies the maximum time duration value as 20 times (1/0.05) longer than the original time duration. In order to figure out the LNG bunkering operational safety with a safety factor of 3.0,95\% fractile values were calculated from the Weibull fitting and the PDF of extreme value distribution.

An example of the positive peak sampling is shown in Fig. 14 for the $5 \mathrm{~K}$ SP01 tension force in DOENV04. The three-parameter Weibull fitting and the 95\% fractile extreme values of the 5K SP01 tensile load are shown in Fig. 15. 


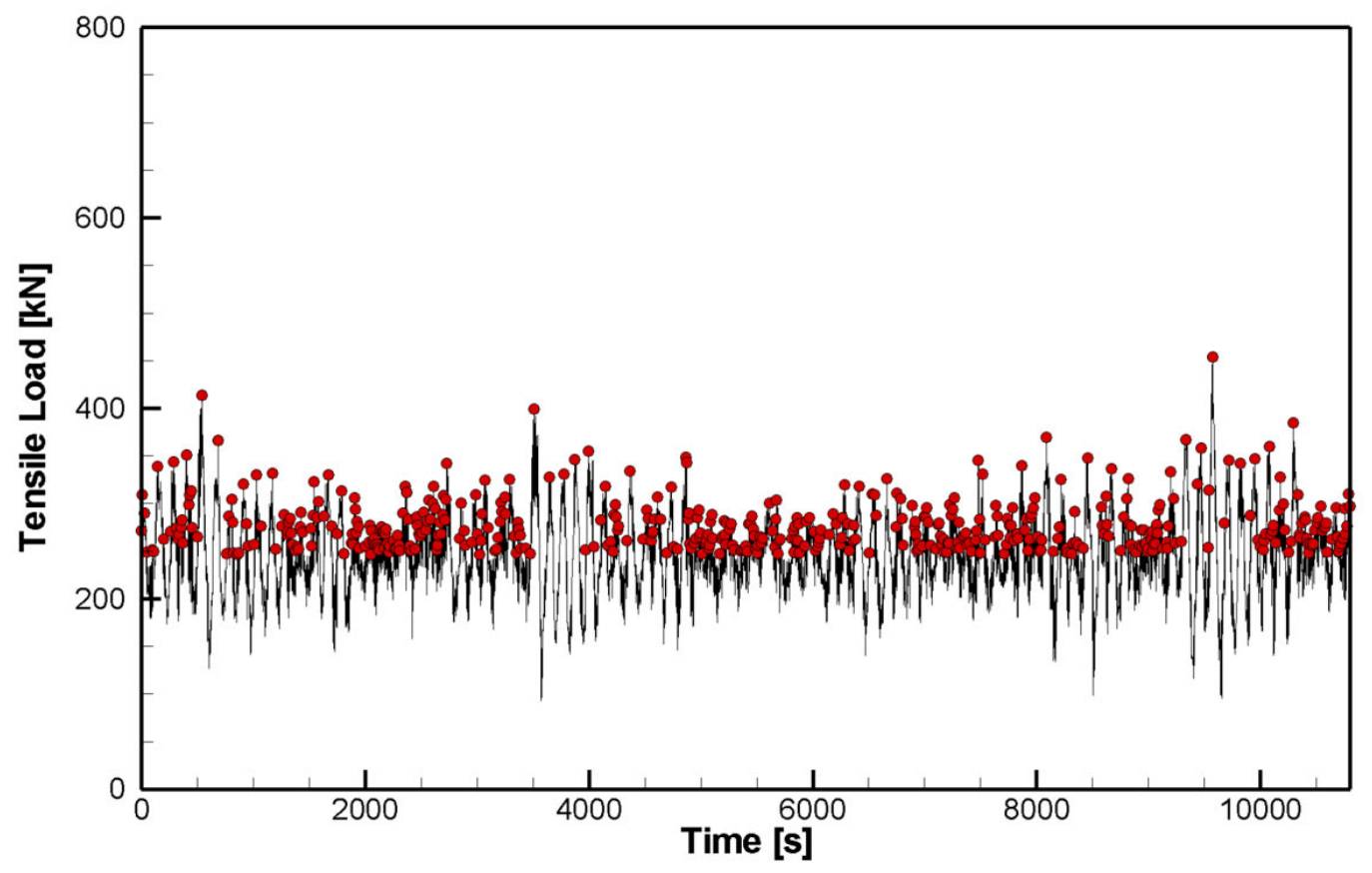

Fig. 14 Tensile load on 5K SP01 in DOENV04 (with positive peaks).

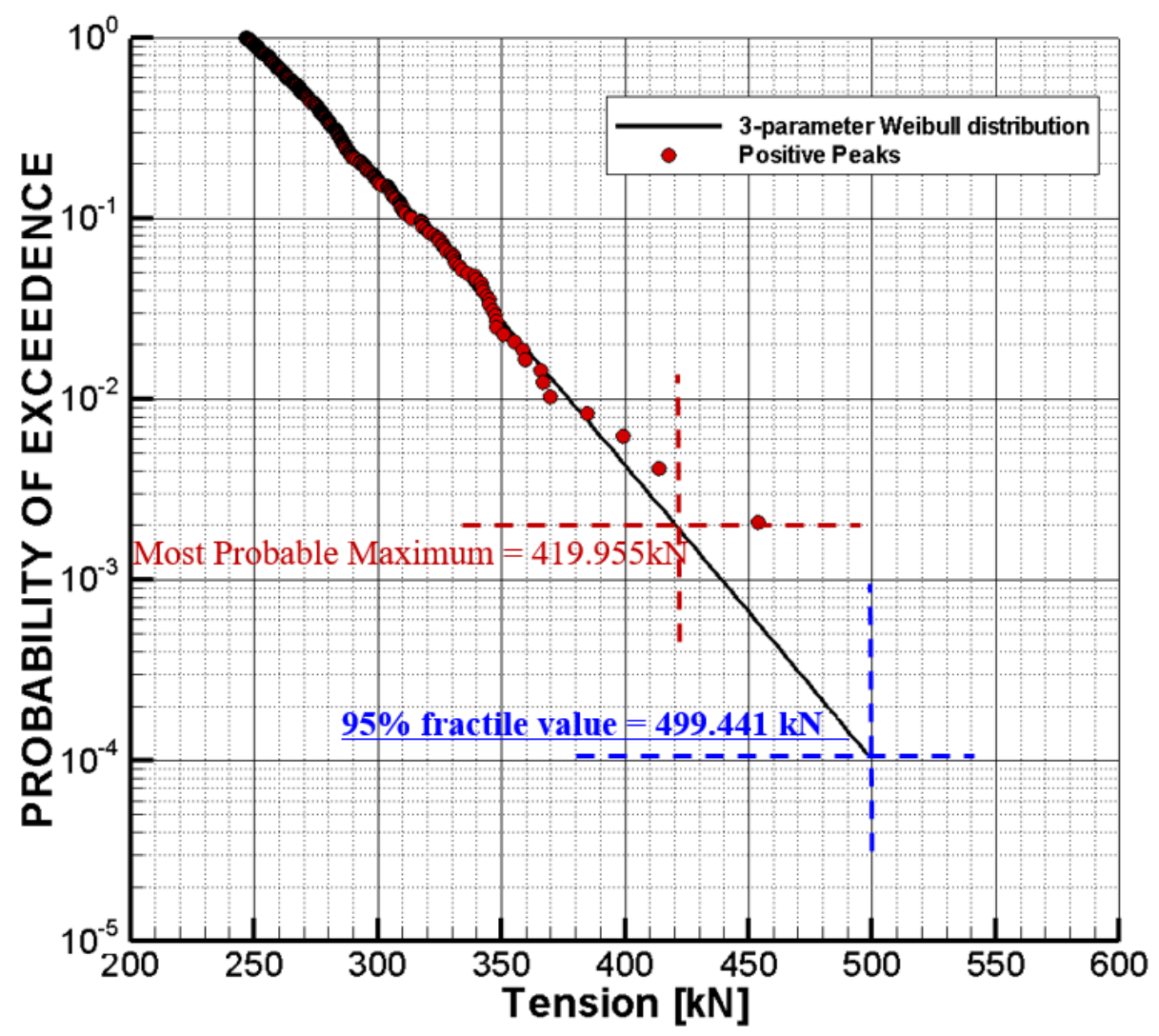

Fig. 15 The three-parameter Weibull fitting and the 95\% fractile value of tension (SP01-5K) in Test ID = 1204 .

These statistically extreme values were compared with the designed criteria. To evaluate the safe LNG bunkering operation, two criteria are representative. One is the structural response of the side-by-side hawsers and fenders compared to their maximum breaking limits (MBLs), and the other is the relative motion between the LNG loading arm installation 
YH Kim, DW Jung, HD Song, YU Won, DH Jung
Experimental Study on Coordinated Heading Control of Four Vessels Moored Side by Side

position and the corresponding manifold compared to the allowable motion criteria of the loading arm. While the two assessments are complementary, we evaluated the process reliability with structural responses for the side-by-side mooring system. The $95 \%$ fractile values were calculated using the experimental data and then compared with their MBLs. Table 6 to 8 show the Weibull fitting parameters, shape parameter, and location parameters from the STS mooring system responses, respectively.

Table 6 Weibull distribution parameters of the STS mooring system positive peaks - Scale parameter, $\gamma$

\begin{tabular}{|c|c|c|c|c|c|c|c|c|c|c|c|c|c|c|c|c|c|c|c|c|}
\hline & \multicolumn{20}{|c|}{ Test ID } \\
\hline & 1201 & 1202 & 1203 & 1204 & 1302 & 1304 & 1306 & 1308 & 1402 & 1404 & 1406 & 1408 & 1502 & 1504 & 1506 & 1508 & 1602 & 1604 & 1606 & 1608 \\
\hline SP01-170K[kN] & 69.00 & 79.20 & 203.82 & 58.27 & 76.96 & 108.98 & 153.14 & 216.02 & 51.49 & 63.06 & 72.58 & 112.81 & 171.81 & 316.86 & 294.32 & 231.45 & 57.14 & 72.93 & 82.05 & 90.68 \\
\hline SP02-170K[kN] & 102.18 & 2.36 & 273.71 & 70.90 & 107.62 & 158.03 & 217.07 & 299.49 & 63.20 & 102.15 & 125.45 & 146.91 & 240.48 & 437.08 & 410.88 & 327.81 & 72.89 & 92.69 & 105.75 & 119.75 \\
\hline SP03-170K $[\mathrm{kN}]$ & 120.10 & 94.53 & 290.81 & 69.38 & 123.49 & 184.62 & 246.06 & 330.70 & 81.23 & 108.26 & 142.44 & 160.48 & 269.56 & 466.90 & 437.89 & 338.28 & 65.25 & 88.10 & 108.87 & 123.85 \\
\hline $\mathrm{SP} 04-170 \mathrm{~K}[\mathrm{kN}]$ & 28.90 & 35.70 & 69.59 & 18.79 & 35.89 & 22.58 & 39.76 & 72.63 & 30.42 & 29.61 & 50.04 & 47.42 & 59.78 & 132.83 & 121.14 & 131.21 & 19.62 & 23.17 & 5.95 & 26.73 \\
\hline $\mathrm{SP} 05-170 \mathrm{~K}[\mathrm{kN}]$ & 3.92 & 4.69 & 8.81 & 5.16 & 4.66 & 3.67 & 4.30 & 9.75 & 7.56 & 4.63 & 12.15 & 13.26 & 9.21 & 10.72 & 11.24 & 7.94 & 4.79 & 2.22 & 4.68 & 13.51 \\
\hline SP06-170K[kN] & 38.52 & 35.41 & 111.06 & 18.42 & 44.64 & 46.67 & 91.72 & 124.74 & 27.18 & 25.01 & 44.94 & 43.24 & 82.72 & 139.45 & 114.88 & 142.85 & 13.67 & 14.42 & 30.41 & 36.55 \\
\hline SP07-170K[kN] & 72.46 & 74.11 & 206.69 & 38.67 & 76.32 & 97.12 & 182.94 & 246.08 & 60.42 & 44.96 & 90.00 & 86.90 & 156.98 & 270.09 & 219.33 & 264.78 & 33.34 & 44.03 & 62.73 & 74.15 \\
\hline SP08-170K[kN] & 117.41 & 125.52 & 378.87 & 87.48 & 112.87 & 204.94 & 322.35 & 440.51 & 73.68 & 78.62 & 118.62 & 90.49 & 266.26 & 508.57 & 422.88 & 451.52 & 39.00 & 49.41 & 109.70 & 143.38 \\
\hline SP09-170K[kN] & 106.19 & 120.16 & 293.16 & 91.01 & 100.16 & 169.12 & 248.27 & 335.36 & 58.68 & 81.86 & 100.25 & 50.00 & 199.38 & 401.07 & 335.78 & 349.75 & 41.43 & 46.44 & 92.71 & 135.87 \\
\hline SP01-30K[kN] & 48.51 & 30.52 & 48.22 & 22.91 & 54.26 & 44.85 & 49.61 & 62.72 & 33.49 & 29.15 & 27.16 & 26.96 & 43.89 & 65.03 & 42.63 & 23.98 & 25.86 & 21.89 & 22.58 & 21.12 \\
\hline $\mathrm{SP} 02-3$ & 57.20 & 35.88 & 53.56 & 27.49 & 65.37 & 51.70 & 56.21 & 69.67 & 38.71 & 32.69 & 30.90 & 31.56 & 48.11 & 75.16 & 50.53 & 26.85 & 29.71 & 25.93 & 26.23 & 23.91 \\
\hline SP03-30K[kN] & 59.24 & 36.07 & 52.45 & 26.43 & 68.67 & 52.84 & 57.09 & 69.68 & 35.08 & 32.21 & 31.58 & 31.52 & 47.40 & 5.05 & 50.98 & 25.69 & 30.73 & 21.27 & 26.35 & 23.78 \\
\hline SP04-30K[kN] & 51.30 & 25.89 & 32.35 & 18.31 & 56.64 & 48.33 & 48.46 & 53.26 & 28.13 & 24.70 & 17.90 & 20.74 & 26. & 36.93 & 10.65 & 37 & 20.09 & & 16 & 64 \\
\hline $\mathrm{SP} 05-30 \mathrm{~K}[\mathrm{kN}]$ & 50.48 & 35.66 & 33.06 & 27.01 & 58.00 & 43.93 & 43.80 & 53.00 & 39.58 & 29.86 & 30.18 & 28.28 & 30.20 & 44.26 & 30.82 & 20.55 & 33.86 & 24.23 & 24.39 & 23.96 \\
\hline SP06-30K[kN] & 229.95 & 168.18 & 187.55 & 116.17 & 250.73 & 230.36 & 229.29 & 265.45 & 181.23 & 121.63 & 105.84 & 102.89 & 170.22 & 268.57 & 230.78 & 176.52 & 145.31 & 83.35 & 75.83 & 61.43 \\
\hline SP07-3 & 236.10 & 263.27 & 154.29 & 191.28 & 261.81 & 214.47 & 169.78 & 187.32 & 286.87 & 191.08 & 159.64 & 161.75 & 138.87 & 283.33 & 256.72 & 163.23 & 243.46 & 140.74 & 132.10 & 119.41 \\
\hline SP08-30K[kN] & 163.67 & 149.59 & 151.90 & 109.22 & 173.45 & 164.73 & 160.06 & 187.61 & 162.28 & 100.80 & 93.47 & 95.20 & 142.64 & 238.63 & 220.27 & 156.82 & 136.44 & 79.54 & 73.81 & 68.68 \\
\hline SP01-05K[kN] & 71.65 & 80.60 & 129.64 & 65.79 & 73.23 & 80.28 & 96.54 & 109.19 & 107.54 & 67.03 & 63.36 & 66.94 & 109.65 & 144.52 & 131.89 & 151.18 & 74.91 & 37.04 & 53.21 & 49.12 \\
\hline SP02-05K[kN] & 79.69 & 72.03 & 150.99 & 62.62 & 83.58 & 100.54 & 116.37 & 125.45 & 121.14 & 72.81 & 69.88 & 77.75 & 133.03 & 162.94 & 171.26 & 190.30 & 73.20 & 37.50 & 56.21 & 55.36 \\
\hline SP03-05K[k & 107.45 & 202.94 & 207.47 & 165.22 & 102.58 & 172.73 & 204.34 & 238.08 & 266.06 & 133.16 & 80.07 & 117.41 & 205.07 & 314.00 & 320.14 & 376.64 & 191.52 & 80.92 & 72.44 & 38.24 \\
\hline SP04-05K[kN] & 45.91 & 106.98 & 63.42 & 79.50 & 52.05 & 54.73 & 62.19 & 95.10 & 128.13 & 53.60 & 28.24 & 22.98 & 53.62 & 128.82 & 90.84 & 125.88 & 95.59 & 31.33 & 27.58 & 16.92 \\
\hline SP05-05K[kN] & 34.03 & 93.17 & 36.43 & 65.26 & 35.19 & 14.14 & 20.15 & 64.49 & 120.26 & 46.83 & 26.42 & 26.66 & 26.80 & 111.19 & 25.92 & 91.15 & 71.24 & 31.87 & 15.54 & 14.77 \\
\hline SP06-05K[kN] & 61.26 & 191.29 & 151.01 & 130.45 & 86.47 & 80.72 & 90.89 & 85.64 & 239.02 & 125.00 & 70.39 & 63.09 & 119.75 & 266.56 & 133.73 & 114.98 & 163.91 & 73.12 & 62.89 & 70.65 \\
\hline $\mathrm{SP} 07-05 \mathrm{~K}[\mathrm{kN}]$ & 43.75 & 117.21 & 109.10 & 77.56 & 59.85 & 60.17 & 73.52 & 66.69 & 141.12 & 81.80 & 62.97 & 57.76 & 87.37 & 170.81 & 84.48 & 100.57 & 102.05 & 47.71 & 51.36 & 57.37 \\
\hline & & & & & 59.66 & 69.41 & 18.30 & 140.45 & 68.17 & 88.00 & 97.88 & 129.59 & 126.28 & 244.98 & 259.05 & 236.72 & 34.55 & 63.58 & 77.20 & 87.85 \\
\hline FD02-170K $[\mathrm{kN}]$ & 54.77 & 90.94 & 43.38 & 58.72 & 57.32 & 65.16 & 16.57 & 119.52 & 69.19 & 86.67 & 96.10 & 124.78 & 113.07 & 230.57 & 261.98 & 246.18 & 54.10 & 62.01 & 71.65 & 85.18 \\
\hline FD03-170K $[\mathrm{kN}]$ & 62.37 & 95.22 & 105.85 & 79.81 & 60.73 & 23.51 & 71.25 & 90.33 & 82.03 & 40.34 & 93.39 & 116.26 & 53.04 & 162.74 & 201.66 & 209.18 & 76.03 & 74.61 & 74.57 & 83.65 \\
\hline FD04-170K[kN] & 64.95 & 97.20 & 104.74 & 82.96 & 65.03 & 30.01 & 82.45 & 105.67 & 87.49 & 38.04 & 42.79 & 118.81 & 48.54 & 162.52 & 180.68 & 175.44 & 78.46 & 77.44 & 78.87 & 85.82 \\
\hline FD01-30K[kN] & 87.69 & 53.28 & 176.08 & 19.79 & 105.18 & 151.02 & 170.58 & 208.55 & 64.24 & 55.31 & 61.21 & 70.93 & 164.77 & 224.60 & 218.43 & 210.31 & 52.48 & 43.16 & 52.24 & 55.17 \\
\hline FD02-30K[kN] & 96.28 & 40.62 & 152.03 & 37.39 & 93.90 & 133.91 & 153.12 & 189.03 & 54.29 & 46.28 & & 62.04 & 146.10 & 179.26 & 180.98 & 193.15 & 38.32 & 37.98 & 45.81 & 47.29 \\
\hline FD03-30K[kN] & 87.90 & 20.82 & 112.31 & 31.89 & 87.80 & 110.15 & 123.36 & 149.84 & 42.46 & 38.95 & 45.51 & 51.95 & 108.15 & 144.34 & 163.78 & 171.28 & 33.48 & 33.35 & 38.80 & 41.51 \\
\hline FD04-30K[kN] & 65.98 & 36.06 & 61.68 & 33.34 & 71.05 & 72.04 & 70.41 & 65.74 & 40.22 & 36.75 & 42.22 & 48.80 & 60.28 & 64.32 & 121.97 & 134.05 & 31.52 & 31.76 & 36.16 & 37.68 \\
\hline FD01-05K[kN] & 213.31 & 126.78 & 396.80 & 118.57 & 214.19 & 305.35 & 384.95 & 408.33 & 147.42 & 119.85 & 90.08 & 161.36 & 393.59 & 457.63 & 398.60 & 404.55 & 136.19 & 73.27 & 99.48 & 134.19 \\
\hline FD02-05K[kN] & 154.50 & 82.46 & 258.55 & 70.98 & 150.88 & 221.86 & 259.12 & 276.14 & 94.94 & 76.75 & 69.20 & 123.27 & 266.98 & 287.85 & 268.25 & 258.23 & 83.83 & 18.19 & 70.71 & 102.01 \\
\hline FD03-05K[kN] & 184.58 & 74.63 & 306.08 & 54.98 & 174.11 & 255.22 & 288.27 & 308.59 & 143.95 & 88.39 & 71.62 & 171.04 & 300.59 & 336.48 & 284.73 & 260.47 & 124.71 & 47.70 & 95.66 & 132.28 \\
\hline
\end{tabular}


Table 7 Weibull distribution parameters of the STS mooring system positive peaks - Shape parameter, $\beta$

\begin{tabular}{|c|c|c|c|c|c|c|c|c|c|c|c|c|c|c|c|c|c|c|c|c|}
\hline & \multicolumn{20}{|c|}{ est ID } \\
\hline & 1201 & 1202 & 1203 & 1204 & 1302 & 1304 & 1306 & 1308 & 1402 & 1404 & 1406 & 1408 & 1502 & 1504 & 1506 & 1508 & 1602 & 1604 & 1606 & 1608 \\
\hline SP01-170K[kN] & 1.77 & 2.17 & 1.97 & 1.93 & 2.03 & 1.90 & 1.84 & 1.75 & 1.45 & 1.39 & 1.41 & 1.81 & 1.81 & 2.02 & 2.04 & 1.97 & 1.87 & 2.10 & 2.11 & 1.82 \\
\hline SP02-170K [kN] & 1.85 & 2.19 & 1.90 & 1.86 & 2.01 & 1.97 & 1.87 & 1.78 & 1.39 & 1.64 & 1.74 & 1.81 & 1.80 & 1.95 & 1.95 & 1.96 & 1.86 & 2.11 & 2.08 & 1.85 \\
\hline SP03-170K[kN] & 1.93 & 2.00 & 1.84 & 1.91 & 2.05 & 2.09 & 1.94 & 1.84 & 1.58 & 1.73 & 1.96 & 1.98 & 1.84 & 1.89 & 1.87 & 1.91 & 1.67 & 2.01 & 2.10 & 1.91 \\
\hline SP04-170K [kN] & 1.02 & 1.09 & 1.66 & 0.87 & 1.18 & 0.94 & 1.16 & 1.60 & 0.92 & 0.73 & 1.00 & 1.11 & 1.57 & 2.24 & 2.04 & 1.90 & 0.82 & 0.84 & 0.94 & 1.04 \\
\hline SP05-170K [kN] & 0.80 & 0.86 & 1.33 & 1.33 & 0.89 & 0.87 & 0.98 & 1.18 & 0.84 & 0.68 & 1.50 & 1.60 & 1.20 & 0.90 & 0.78 & 0.84 & 0.82 & 0.68 & 0.97 & 1.84 \\
\hline SP06-170K [kN] & 1.48 & 1.40 & 1.83 & 1.10 & 1.82 & 1.28 & 1.61 & 1.77 & 1.10 & 0.80 & 1.27 & 1.31 & 1.54 & 2.35 & 2.05 & 1.93 & 0.93 & 0.85 & 1.29 & 1.59 \\
\hline SP07-170K [kN] & 1.59 & 1.57 & 1.77 & 1.17 & 1.83 & 1.41 & 1.71 & 1.77 & 1.26 & 0.86 & 1.38 & 1.46 & 1.51 & 2.23 & 1.91 & 1.92 & 1.10 & 1.21 & 1.44 & 1.71 \\
\hline SP08-170K[kN] & 1.83 & 1.66 & 2.05 & 1.50 & 1.88 & 1.79 & 1.98 & 2.02 & 1.11 & 1.02 & 1.32 & 1.21 & 1.63 & 2.48 & 2.13 & 2.19 & 0.90 & 1.04 & 1.63 & 2.02 \\
\hline SP09-170K [kN] & 1.88 & 1.52 & 2.06 & 1.52 & 1.87 & 1.90 & 2.03 & 1.99 & 0.93 & 1.00 & 1.18 & 0.82 & 1.60 & 2.42 & 2.16 & 2.21 & 0.89 & 0.96 & 1.46 & 2.04 \\
\hline SP01-30K[kN] & 1.45 & 1.60 & 1.41 & 1.68 & 1.52 & 1.31 & 1.32 & 1.43 & 1.54 & 1.66 & 1.66 & 1.57 & 1.37 & 1.69 & 1.55 & 1.60 & 1.56 & 1.62 & 1.68 & 1.62 \\
\hline $\mathrm{SP} 02-30 \mathrm{~K}[\mathrm{kN}]$ & 1.41 & 1.57 & 1.39 & 1.70 & 1.51 & 1.30 & 1.32 & 1.41 & 1.50 & 1.54 & 1.56 & 1.55 & 1.34 & 1.72 & 1.59 & 1.55 & 1.53 & 1.61 & 1.63 & 1.56 \\
\hline $\mathrm{SP} 03-30 \mathrm{~K}[\mathrm{kN}]$ & 1.40 & 1.51 & 1.39 & 1.59 & 1.50 & 1.30 & 1.33 & 1.42 & 1.40 & 1.43 & 1.50 & 1.46 & 1.33 & 1.75 & 1.63 & 1.50 & 1.55 & 1.34 & 1.53 & 1.46 \\
\hline $\mathrm{SP} 04-30 \mathrm{~K}[\mathrm{kN}]$ & 1.50 & 1.40 & 1.25 & 1.42 & 1.58 & 1.48 & 1.42 & 1.48 & 1.44 & 1.46 & 1.25 & 1.41 & 1.18 & 1.60 & 0.86 & 1.47 & 1.46 & 1.19 & 1.55 & 1.50 \\
\hline $\mathrm{SP} 05-30 \mathrm{~K}[\mathrm{kN}]$ & 1.51 & 1.70 & 1.44 & 1.79 & 1.64 & 1.47 & 1.44 & 1.64 & 1.86 & 1.44 & 1.52 & 1.44 & 1.35 & 1.77 & 1.69 & 1.73 & 2.09 & 1.63 & 1.53 & 1.62 \\
\hline $\mathrm{SP} 06-30 \mathrm{~K}[\mathrm{kN}]$ & 1.83 & 1.76 & 1.63 & 1.66 & 1.89 & 1.83 & 1.71 & 1.82 & 1.76 & 1.53 & 1.51 & 1.56 & 1.58 & 2.05 & 2.03 & 1.95 & 1.77 & 1.41 & 1.44 & 1.31 \\
\hline SP07-30K[kN] & 1.80 & 1.89 & 1.79 & 1.79 & 1.88 & 1.90 & 1.63 & 1.78 & 1.86 & 1.74 & 1.70 & 1.84 & 1.70 & 2.14 & 2.22 & 2.08 & 1.91 & 1.64 & 1.74 & 1.74 \\
\hline SP08-30K[kN] & 2.18 & 1.97 & 2.00 & 1.89 & 2.17 & 2.21 & 1.98 & 2.09 & 1.92 & 1.66 & 1.71 & 1.85 & 1.93 & 2.39 & 2.39 & 2.39 & 1.98 & 1.66 & 1.72 & 1.72 \\
\hline SP01-05K[kN] & 1.57 & 1.41 & 2.35 & 1.43 & 1.47 & 1.72 & 1.93 & 2.07 & 1.47 & 1.61 & 1.60 & 1.75 & 2.10 & 2.27 & 2.37 & 2.26 & 1.42 & 1.17 & 1.77 & 1.59 \\
\hline $\mathrm{SP} 02-05 \mathrm{~K}[\mathrm{kN}]$ & 1.44 & 1.06 & 2.34 & 1.16 & 1.38 & 1.68 & 1.87 & 2.02 & 1.26 & 1.50 & 1.53 & 1.76 & 2.12 & 2.29 & 2.33 & 2.26 & 1.15 & 1.07 & 1.66 & 1.55 \\
\hline $\mathrm{SP} 03-05 \mathrm{~K}[\mathrm{kN}]$ & 1.43 & 1.30 & 1.47 & 1.32 & 1.40 & 1.76 & 1.82 & 1.53 & 1.40 & 1.42 & 1.24 & 1.62 & 1.59 & 1.62 & 2.08 & 2.07 & 1.34 & 1.16 & 1.56 & 0.91 \\
\hline SP04-05K[kN] & 1.44 & 1.53 & 1.07 & 1.44 & 1.57 & 1.56 & 1.48 & 1.20 & 1.63 & 1.35 & 1.18 & 0.96 & 1.13 & 1.30 & 1.61 & 1.67 & 1.54 & 1.13 & 1.58 & 0.85 \\
\hline $\mathrm{SP} 05-05 \mathrm{~K}[\mathrm{kN}]$ & 1.27 & 1.25 & 0.90 & 1.18 & 1.19 & 0.80 & 0.87 & 1.02 & 1.36 & 1.13 & 1.00 & 1.05 & 0.93 & 1.16 & 0.86 & 1.36 & 1.18 & 1.02 & 0.99 & 0.90 \\
\hline $\mathrm{SP} 06-05 \mathrm{~K}[\mathrm{kN}]$ & 1.06 & 1.45 & 1.52 & 1.23 & 1.14 & 1.58 & 1.47 & 1.06 & 1.50 & 1.44 & 1.11 & 1.15 & 1.51 & 1.61 & 1.42 & 1.25 & 1.36 & 1.10 & 1.24 & 1.37 \\
\hline SP07-05K[kN] & 1.14 & 1.55 & 1.59 & 1.28 & 1.22 & 1.68 & 1.62 & 1.14 & 1.56 & 1.53 & 1.35 & 1.35 & 1.56 & 1.62 & 1.42 & 1.47 & 1.47 & 1.15 & 1.43 & 1.52 \\
\hline FD01-170K $[\mathrm{kN}]$ & 1.67 & 1.97 & 1.33 & 1.79 & 1.78 & 1.88 & 0.70 & 1.72 & 1.40 & 1.46 & 1.51 & 2.03 & 1.72 & 1.62 & 1.68 & 1.86 & 1.17 & 1.69 & 1.66 & 1.85 \\
\hline $\mathrm{FD} 02-170 \mathrm{~K}[\mathrm{kN}]$ & 1.70 & 1.97 & 0.89 & 1.69 & 1.76 & 1.83 & 0.69 & 1.63 & 1.44 & 1.45 & 1.52 & 2.03 & 1.69 & 1.61 & 1.72 & 1.79 & 1.56 & 1.73 & 1.57 & 1.83 \\
\hline FD03-170K $[\mathrm{kN}]$ & 1.75 & 2.30 & 1.81 & 2.30 & 1.88 & 0.80 & 1.50 & 1.40 & 1.95 & 1.01 & 1.55 & 1.98 & 1.16 & 1.55 & 1.58 & 1.46 & 2.31 & 2.10 & 1.63 & 1.79 \\
\hline FD04-170K $[\mathrm{kN}]$ & 1.76 & 2.29 & 1.61 & 2.34 & 1.93 & 0.82 & 1.52 & 1.36 & 1.94 & 0.95 & 0.98 & 1.94 & 0.99 & 1.55 & 1.49 & 1.30 & 2.32 & 2.07 & 1.69 & 1.78 \\
\hline FD01-30K[kN] & 1.48 & 1.31 & 1.80 & 0.96 & 1.66 & 1.80 & 1.66 & 1.66 & 1.38 & 1.71 & 1.92 & 1.89 & 1.75 & 1.62 & 1.61 & 1.86 & 1.46 & 1.78 & 2.02 & 1.92 \\
\hline $\mathrm{FD} 02-30 \mathrm{~K}[\mathrm{kN}]$ & 1.87 & 1.34 & 2.10 & 1.63 & 1.86 & 1.99 & 1.93 & 2.11 & 1.50 & 1.75 & 1.92 & 1.92 & 2.08 & 2.07 & 2.00 & 2.13 & 1.45 & 1.92 & 2.04 & 1.94 \\
\hline FD03-30K $[\mathrm{kN}]$ & 2.10 & 1.14 & 2.17 & 1.86 & 2.16 & 2.15 & 2.12 & 2.35 & 1.63 & 1.74 & 1.85 & 1.88 & 2.13 & 2.37 & 2.36 & 2.27 & 1.70 & 2.02 & 1.99 & 1.99 \\
\hline FD04-30K[kN] & 1.98 & 1.76 & 2.10 & 2.31 & 2.13 & 2.16 & 2.02 & 1.90 & 1.86 & 1.84 & 1.89 & 2.04 & 2.12 & 1.77 & 2.43 & 2.44 & 1.90 & 2.01 & 2.00 & 2.10 \\
\hline FD01-05K[kN] & 1.89 & 1.44 & 2.52 & 1.65 & 1.89 & 2.34 & 2.77 & 2.73 & 1.35 & 1.83 & 1.44 & 1.98 & 2.62 & 2.41 & 2.14 & 2.08 & 1.58 & 1.45 & 1.88 & 2.05 \\
\hline FD02-05K[kN] & 1.90 & 1.79 & 2.10 & 1.90 & 1.99 & 2.26 & 2.42 & 2.29 & 1.84 & 1.97 & 1.60 & 2.04 & 2.28 & 2.01 & 2.33 & 2.43 & 2.15 & 0.87 & 2.03 & 2.09 \\
\hline FD03-05K[kN] & 1.90 & 1.11 & 1.90 & 1.00 & 1.88 & 2.18 & 2.18 & 1.94 & 1.48 & 1.38 & 1.16 & 1.92 & 2.05 & 1.67 & 2.19 & 2.02 & 1.69 & 0.98 & 1.73 & 1.86 \\
\hline
\end{tabular}

Table 8 Weibull distribution parameters of the STS mooring system positive peaks - Location parameter, $\delta$

\begin{tabular}{|c|c|c|c|c|c|c|c|c|c|c|c|c|c|c|c|c|c|c|c|c|}
\hline & \multicolumn{20}{|c|}{ Iest } \\
\hline & & 1202 & 203 & 1204 & 1302 & 304 & 1306 & & 1402 & 1404 & 1406 & 1408 & 1502 & & 506 & & 602 & & & \\
\hline & & .53 & & & & & & & & & & & & & & & & & 1.47 & \\
\hline & & 45 & & & & & & & & .77 & & & & & & & & & & \\
\hline & 1.50 & & & & & & & & & 6.85 & & & & & & & & & & \\
\hline & 18 & & & 74 & & & 21 & & & 2.92 & 12 & & & & & & & & & \\
\hline & & & & & & & & & & & & & & & & & & & & \\
\hline & & & & & & & & & & 56 & & & & & & & & & & \\
\hline & 2 & 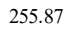 & & & & & & & & 15.80 & 283. & & & & & & & & & \\
\hline & 0.9 & 9 & & 4 & & & & & & 23.41 & 448.70 & & & & & & & & & \\
\hline & 6.50 & 8.75 & & 196.63 & 80 & 147.90 & 1.86 & 48.85 & 9.99 & 261.99 & 218.95 & 430.62 & & 18.69 & & & & & & \\
\hline & & & & & & & & & & & & & & & & & & & & \\
\hline & & & & & & & & & & 3.16 & & & & & & & & & & \\
\hline & 14 & & & & & & & & & 43.79 & 04 & & & & & & & & & \\
\hline & & & & & & & & & & 86 & & & & & & & & & & \\
\hline & & & & & & & & & & 79 & & & & & & & & & & \\
\hline & & & & & & & & & & 5.25 & & & & & & & & & & \\
\hline & & & & & & & & & & 47.56 & & & & & & & & & & \\
\hline & 11 & & & 129. & 18 & 115. & & 7 & & 146.21 & 141 & & & & & & & & & \\
\hline & & & & & & & & & & 0 & & & & & & & & & & \\
\hline & & & & & & & & & & & & & & & & & & & & \\
\hline & & 3.80 & & 2 & & & & & & 7.93 & & & & & & & & & & \\
\hline & 1 & & & & & & & & & 73.79 & & & & & & & & & & \\
\hline & 9.66 & 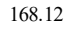 & & & & & & & & 160.54 & & & & & & & & & & \\
\hline & & & & & & & & & & 35 & & & & & & & & & & \\
\hline & 152.66 & 2.14 & 6.44 & 130.46 & 126.20 & 118.93 & 125.68 & 193.07 & 118.00 & 118.96 & 136.72 & 16.03 & 128.66 & 123.43 & 122.79 & & 118.38 & 68 & 2.11 & \\
\hline & & & & & & & & & & & & & & & & & & & & \\
\hline & & & & & & & & & & 425.26 & & & & & & & & & & \\
\hline & 136.28 & 93.21 & 9.53 & 118.35 & 9.26 & 87.42 & 3.15 & & 112.81 & 14 & & & & 1.82 & & & 116.14 & & & \\
\hline FD04-17 & 70.24 & 19.10 & 84.09 & 48.76 & 65.84 & 271.31 & 162.72 & 207.67 & 45.47 & 225.56 & 251.42 & 156.44 & 150.28 & 158.51 & 189.81 & 265.04 & 49.35 & 112.62 & 141.58 & 169.49 \\
\hline & 8.96 & 8.73 & 0.31 & 286.28 & 5.70 & 216.05 & 3.69 & 3.45 & 222.58 & 205.85 & 195.44 & 205.16 & 228.53 & 221.14 & 216.70 & 215.96 & 223.00 & 207.70 & 8.35 & \\
\hline & & & & & & & & & & 180.77 & & & & & & & 82 & & & \\
\hline & & & & & & & & & & & & & & & & & & & & \\
\hline & 131.08 & 125.47 & 1.42 & 122.17 & 129.32 & 140.31 & 152.54 & 157.24 & 126.01 & 136.25 & & 41.00 & 137.49 & 59.36 & & & 30.16 & & 13.37 & 146.00 \\
\hline & 209.57 & 39.31 & & 206.23 & 200.19 & & 5.91 & & & 3.54 & 3.59 & .79 & .10 & 8.66 & 165.98 & 4.95 & 99.75 & 2.91 & 6.34 & 71.73 \\
\hline & & & & 176 & & 151 & & & & 159.62 & & & & & & & .62 & 19 & .23 & 39.36 \\
\hline & & & 188.20 & 286.57 & 180.02 & 162.62 & 162.95 & 159.78 & 197.85 & 208.58 & 244.41 & 145.89 & 183.18 & 192.48 & 150.15 & & 180.73 & 264.31 & 166.9 & \\
\hline
\end{tabular}




\subsection{Collinear condition}

The collinear environmental conditions DOENV02 and DOENV04 are considered first. The compressive loads on the fenders are shown in Fig. 16, and the tensile loads on the mooring ropes are shown in Fig. 17 (left for DOENV02 and right for DOENV04). Since two adjacent mooring ropes were modelled as one experimental spring-wire device in the mooring rope, the compared MBLs are doubled.

The fenders between the FLBT and the 30K LNGBS exhibit the minimum structural response in both environments, while those between the FLBT and the LNGC, and those between the FLBT and the 5K LNGBS have relatively similar loads in DOENV04. Compared to the MBLs of the fenders between the FLBT and the LNGC $(5,860 \mathrm{kN})$ and between the FLBT and two LNGBSs $(2,783 \mathrm{kN})$, the experimental results show lower values. As the repulsive force components are dominant when four vessels are located in close proximity [9], the fenders appear to be reliable in these environments.

As the control heading decreases from $+10^{\circ}$ to $-30^{\circ}$, the structural responses of the fenders and hawsers generally decrease for the 'FLBT-30K LNGBS' and the 'FLBT-5K LNGBS', while they increase for the 'FLBT-LNGC'. The control heading angle decreases below $0^{\circ}$; the two bunkering shuttles are protected from waves and currents by the FLBT and LNGC, while the LNGC is more exposed to them. The shielding effects on operational vessels are clearly shown in the experimental data.

In contrast to the fenders, some experimental responses exceeded the breaking criteria, such as 5K SP03 and 5K SP06 in both environments where 5K LNGBS directly faces incident waves and currents. It seems that the 5K LNGBS is vulnerable in the LNG bunkering operation without any shielding structures, even when the ocean environment is mild. Based on this view, this system can be operated with $-10^{\circ}$ heading control facing environmental loads in the collinear condition.

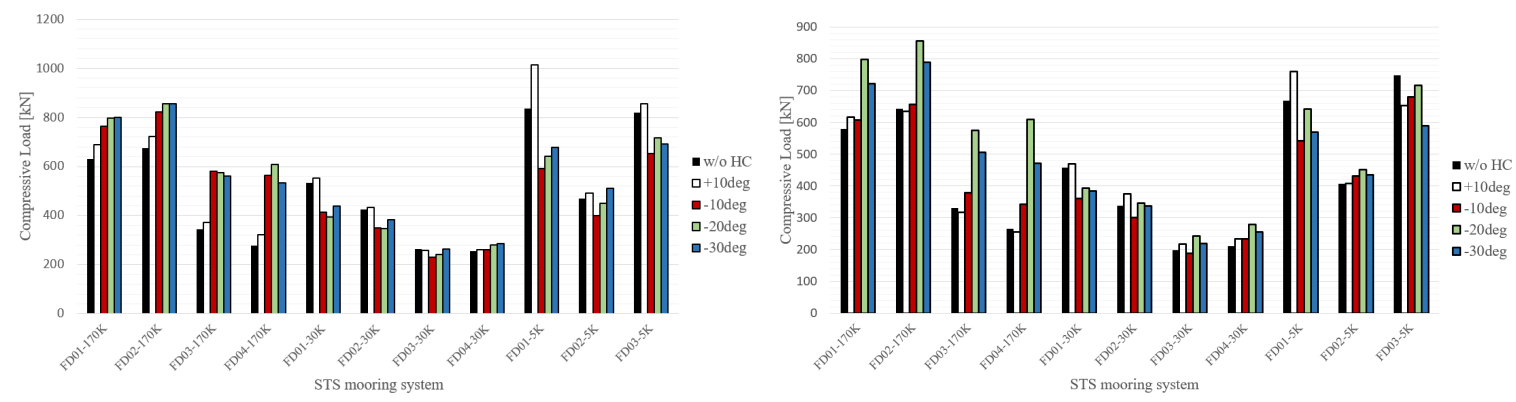

Fig. 16 Statistical extreme compressive loads on fenders in DOENV02 (left) and DOENV04 (right). 


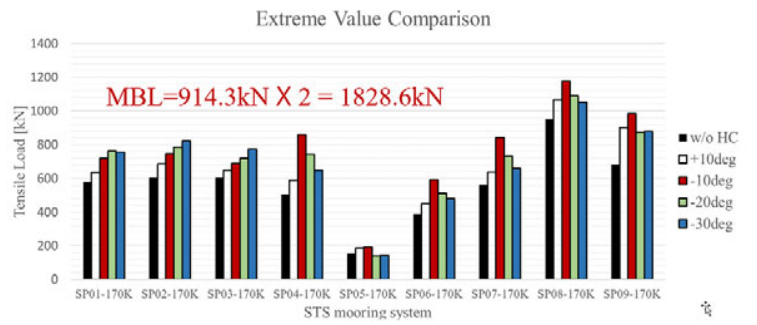

(a.1) Mooring ropes between the FLBT and the LNGC.

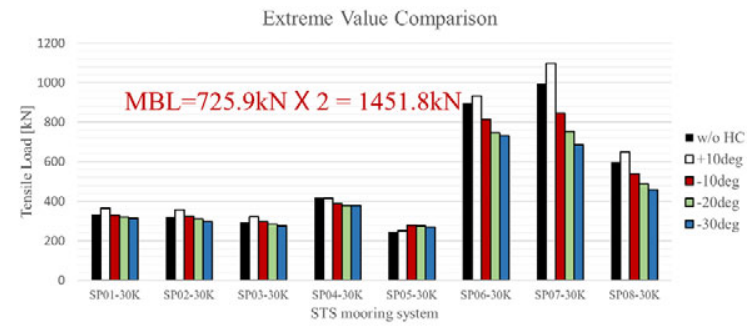

(a.2) Mooring ropes between the FLBT and the $30 \mathrm{~K}$ LNGBS.

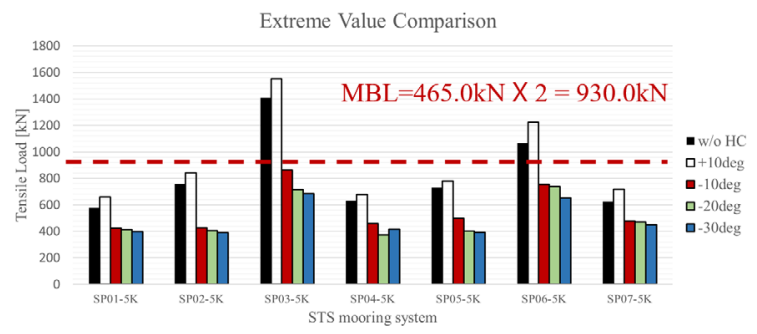

(a.3) Mooring ropes between the FLBT and the 5K LNGBS.

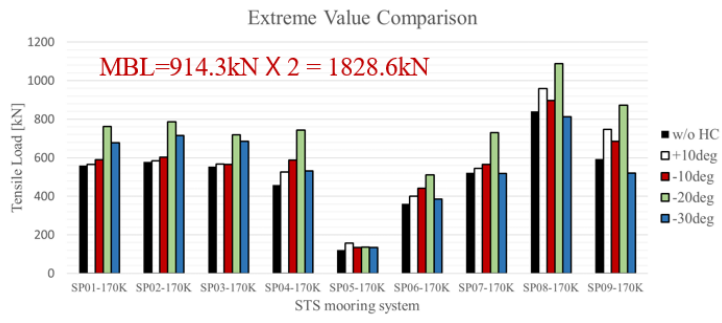

(b.1) Mooring ropes between the FLBT and the LNGC.

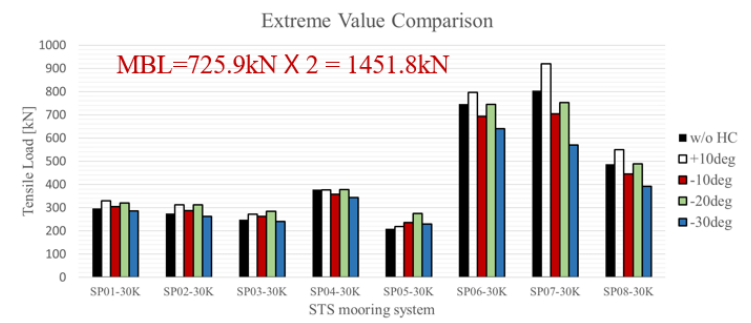

(b.2) Mooring ropes between the FLBT and the $30 \mathrm{~K}$ LNGBS.

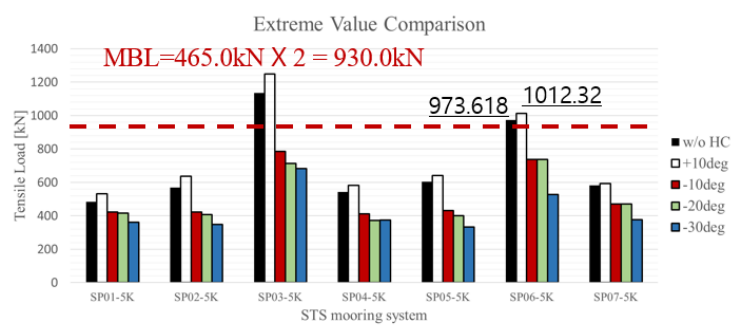

(b.3) Mooring ropes between the FLBT and the $5 \mathrm{~K}$ LNGBS.

Fig. 17 Statistical extreme tensile loads on mooring ropes in DOENV02 (left) and DOENV04 (right).

\subsection{Non-collinear condition}
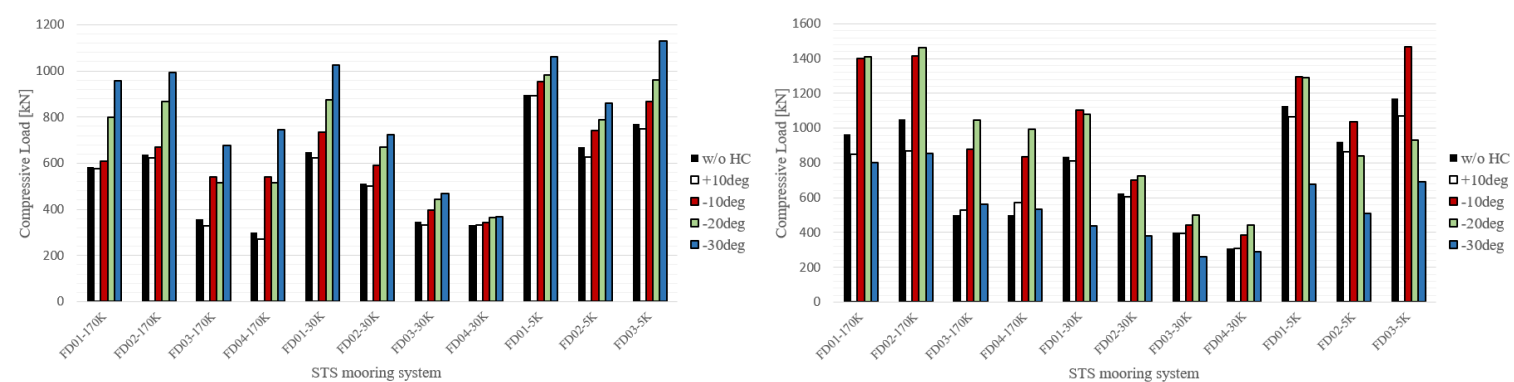

Fig. 18 Statistical extreme compressive loads on fenders in DOENV01 (left) and DOENV03 (right). 
YH Kim, DW Jung, HD Song, YU Won, DH Jung

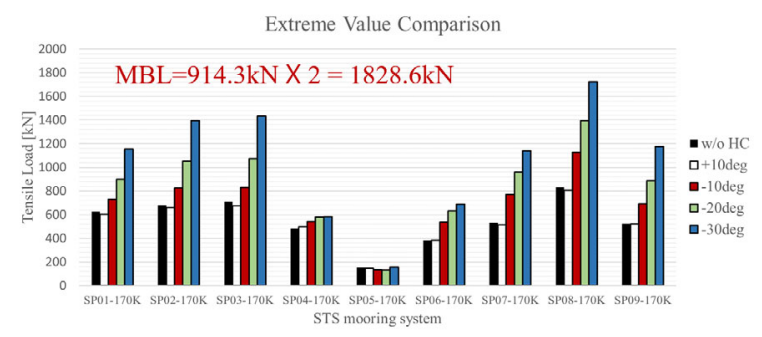

(a.1) Mooring ropes between the FLBT and the LNGC.

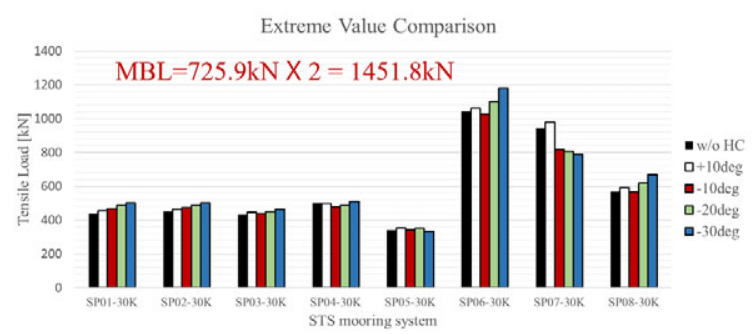

(a.2) Mooring ropes between the FLBT and the $30 \mathrm{~K}$ LNGBS.

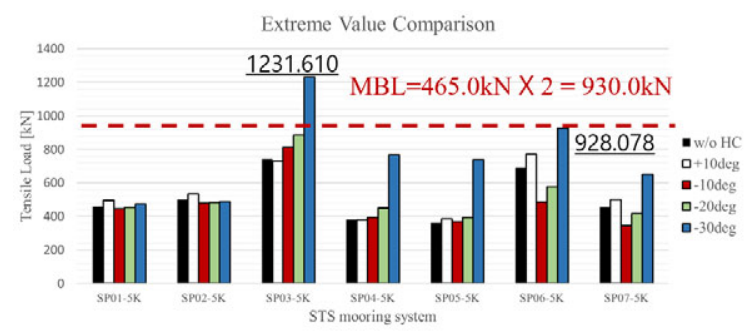

(a.3) Mooring ropes between the FLBT and the 5K LNGBS.
Experimental Study on Coordinated Heading Control of Four Vessels Moored Side by Side

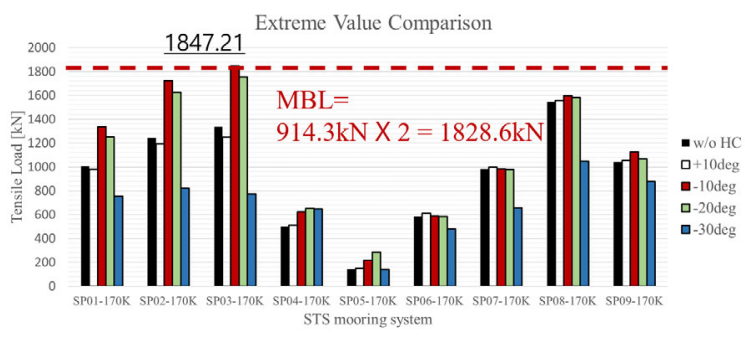

(b.1) Mooring ropes between the FLBT and the LNGC.

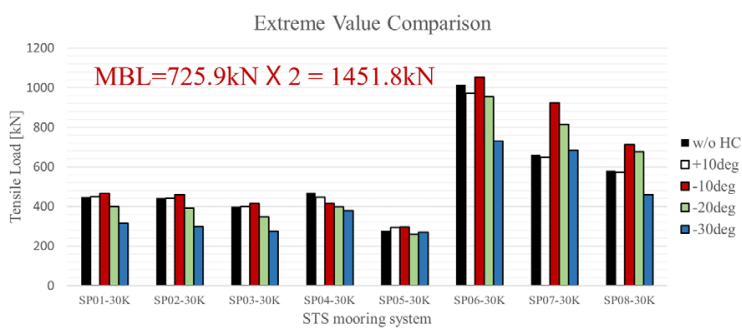

(b.2) Mooring ropes between the FLBT and the 30K LNGBS.

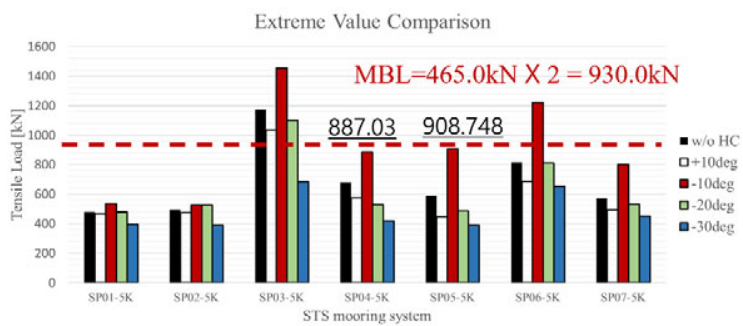

(b.3) Mooring ropes between the FLBT and the $5 \mathrm{~K}$ LNGBS.

Fig. 19 Statistical extreme tensile loads on mooring ropes in DOENV01 (left) and DOENV03 (right).

The two non-collinear conditions, DOENV01 and DOENV03, are evaluated subsequently. Similar to Figs. 16 and 17, the compressive loads on fenders are shown in Fig. 18, and the tensile loads on the mooring ropes are shown in Fig. 19. The relative headings to incident waves are $22.5^{\circ}$ and $67.5^{\circ}$ for DOENV01 and DOENV03 from the $180^{\circ}$ heading of the FLBT. The compressive loads on the fenders are also not significant in non-collinear conditions; therefore, the repulsive forces induced by gap flows still form with different incoming waves and currents.

The shielding characteristics in DOENV01 are different from those in DOENV02. The tension forces between the FLBT and LNGC increase as the control heading is reduced, which is identical to the DOENV02 results. While the tension forces between the FLBT and the 30K LNGBS, and between the FLBT and the 05 LNGBS also increase, the two bunkering shuttles are relatively shielded for all control headings. As the four vessels are fully connected by the side-by-side mooring system, we presumed that this incremental change in the mooring rope tension at the two bunkering shuttles is induced by the enlarged LNGC motion. The increased heave motion from the case without heading control and that with $-30^{\circ}$ heading control is shown in Fig. 20. For DOENV01, the $-30^{\circ}$ heading control condition is not suitable to the LNG bunkering operation for the $5 \mathrm{~K}$ LNGBS. 
The LNG bunkering operation does not seem to be reliable for DOENV03 which has the largest relative incoming wave heading. There is a failure in a mooring rope between the FLBT and the LNGC, which does not occur in any other cases. Only one heading control condition is safe for the $5 \mathrm{~K}$ LNGBS, the $-30^{\circ}$ heading control system. When two environmental loads are incoming at significantly different angles, other optimal headings must be found, considering the shielding effect on the two bunkering shuttles.

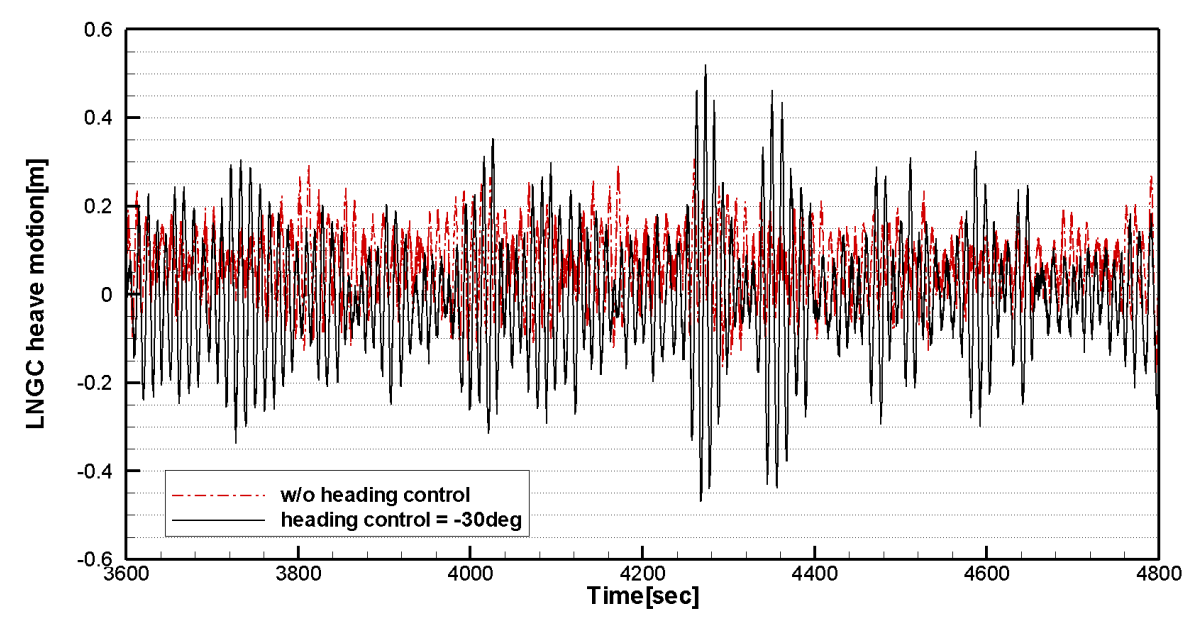

Fig. 20 Time series of LNGC heave without heading control and with $-30^{\circ}$ heave motion in DOENV01.

\section{Conclusion}

We evaluated the LNG bunkering operational feasibility of an FLBT during the side-byside mooring with an LNGC, a 30K LNGBS, and a 5K LNGBS using the FLBT heading control system. A series of model experiments were conducted in the KRISO ocean engineering basin. The results from the white noise test in the head sea condition were compared with those of numerical calculations to validate the experimental setup and assess the system characteristics. Four combined environments with waves and currents that had a one-year return period were considered with five different heading control conditions. Conclusions were obtained as follows:

(1) The experimental data were in agreement with the numerical results, except for the motion responses of the $5 \mathrm{~K}$ LNGBS and the structural responses of the sideby-side mooring ropes installed in the $5 \mathrm{~K}$ LNGBS. The flow was violently disturbed by other vessels in the experiments, and only the results of the $5 \mathrm{~K}$ LNGBS were significantly affected by the diffracted waves. Other vessels, which had significantly larger displacements, were not influenced by the narrow gap effects. Thus, more precise gap flow modelling must be implemented in the numerical simulation based on the boundary element method.

(2) The designed heading control system could provide a proper thrust force from $+10^{\circ}$ to $-30^{\circ}$ in all the considered operational environments. In addition, the FLBT was properly set to the controlled heading angle. As the static equilibrium yaw position without the heading control was approximately $+7^{\circ}$, the $+10^{\circ}$ heading control needed a weaker thrust force. The yaw motions of all the other vessels followed the controlled FLBT yaw angle as they were moored side by side with a large number of mooring ropes and fenders.

(3) The maximum experimental quantities were represented by the $95 \%$ fractile extreme values which were determined using the three-parameter Weibull fitting and the probability density function of the extreme value distribution. 
(4) Under both collinear and non-collinear conditions, compressive loads on the fenders were significantly lower than their maximum breaking limits. The gap flows between the vessels acted as a repulsive force in all the considered environments.

(5) Under collinear conditions, the heading control conditions below $-10^{\circ}$ enabled the side-by-side LNG bunkering operation to be available as tensile loads acting on the mooring ropes between the FLBT and the 5K LNGBS, thereby satisfying the maximum breaking load criteria. The controlled angle for the shielding effect on the 5K LNGBS was small, and this configuration could safely perform the LNG bunkering operation. All other side-by-side mooring ropes were safe, those between the FLBT and the LNGC and those between the FLBT and the 30K LNGBS.

(6) Under non-collinear conditions, the vessel shielding effect tendencies were different. The initial relative incoming wave angle to the LNGC was $22.5^{\circ}$, and the LNGC exhibited significant motion responses. As all the vessels were moored side by side simultaneously, the enlarged LNGC motions triggered stronger structural responses on the mooring ropes between the FLBT and the $30 \mathrm{~K}$ LNGBS, and the FLBT and the 5K LNGBS. The two bunkering shuttles were relatively shielded in all control headings. This phenomenon prohibited safe bunkering operation under the $-30.0^{\circ}$ heading control. With a relative incoming angle of $67.5^{\circ}$, the LNG bunkering operation appeared to be unreliable. There was a failure in a mooring rope between the FLBT and the LNGC, which did not occur in any other case. Only one heading control condition was safe for the $5 \mathrm{~K}$ LNGBS, the $-30^{\circ}$ heading control condition.

Further research must be conducted numerically. The disturbance of incoming flows should be precisely modelled and applied to the floater motion dynamics. The general safety operational heading conditions must be evaluated using a rigorous numerical scheme in all possible operational environments to verify the operational feasibility of this type of system.

\section{ACKNOWLEDGMENT}

This study was supported by both a grant from the National R\&D Project 'Development of an electric-powered car ferry and a roll-on/roll-off power supply system' funded by the Ministry of Oceans and Fisheries, Korea (PMS4700) and the National R\&D Project 'Development of LNG Bunkering Operation Technologies based on Operation System and Risk Assessment' funded by the Ministry of Oceans and Fisheries, Korea (PMS4680). The authors would like to sincerely thank the KRISO ocean engineering basin technicians for their dedicated efforts.

\section{REFERENCES}

[1] Cockett N. 1997. Neil Cockett on bunkers. United Kingdom: LLP Professional Publishing; ISBN-13:9781850449720 .

[2] Corbett JJ, Winebrake JJ, Grean EH, Kasibhatla P, Eyring V, Lauer A. 2007. Mortality from ship emissions: a global assessment. Environmental Science \& Technology. 41:851208518. https://doi.org/10.1021/es071686z

[3] Schinas O, Butler M. 2016. Feasibility and commercial considerations of LNG-fueled ships. Ocean Engineering. 122:84-96. https://doi.org/10.1016/j.oceaneng.2016.04.031

[4] Ohkusu M. 1974. Ship motions in vicinity of a structure. In: Proceedings of the International Conference on Behavior of Offshore Structure, NIT; Tronheim. Vol. 1, p. 284-306. 
[5] Kodan N. 1984. The motions of adjacent floating structures in oblique wave. Journal of Energy Resources Technology. 106(2):206-213. https://doi.org/10.1115/1.3231038

[6] Fang MC, Kim CH. 1986. Hydrodynamically coupled motions of two ships advancing in oblique waves. Journal of Ship Research. 30(3):159-171. https://doi.org/10.5957/jsr.1986.30.3.159

[7] Fang MC, Chen GR. 2001. The relative motion and wave elevation between two floating structures in waves. In: ISOPE, editor. Proceedings of $11^{\text {th }}$ International Offshore and Polar Engineers, ISOPE; Jun 1722; Stavanger, Norway, p. 361-368.

[8] Buchner B, van DIJK A, de Wilde J. 2001. Numerical multiple-body simulations of side-by-side mooring to an FPSO. In: ISOPE, editor. Proceedings of the $11^{\text {th }}$ International Offshore and Polar Engineers, ISOPE; Jun 17-22, Stavanger, Norway, p. 343-353.

[9] Hong SY, Kim JH, Cho SK, Choi YR, Kim YS. 2005. Numerical and experimental study on hydrodynamic interaction of side-by-side moored multiple vessels. Ocean Engineering. 32:783-801. https://doi.org/10.1016/j.oceaneng.2004.10.003

[10] Huijismans RHM, Pinkster JA, de Wilde J. 2001. Diffraction and radiation of waves around side-by-side moored vessels. In: ISOPE, editor. Proceedings of the $11^{\text {th }}$ International Offshore and Polar Engineers, ISOPE; Jun 17-22, Stavanger, Norway, p. 406-412.

[11] Hong DC, Hong SY, Nam BW, Hong SW. 2013. Comparative numerical study of repulsive drift forces and gap resonances between two vessels floating side-by-side in proximity in head seas using a discontinuous HOBEM and a constant BEM with boundary matching formulation. Ocean Engineering. 72:331-343. https://doi.org/10.1016/j.oceaneng.2013.07.019

[12] Nam BW, Kim Y, Hong SY. 2016. Time-domain simulation of berthing problem between FPSO and shuttle tanker in waves. Applied Ocean Research. 58:49-61. https://doi.org/10.1016/j.apor.2016.03.010

[13] Koop A. 2019. Using CFD to determine scale effects on current loads of offshore vessels in side-by-side configuration. Ocean Engineering. Available online 25 November 2019, 106707. https://doi.org/10.1016/j.oceaneng.2019.106707

[14] Pinkster J, Nienhuis U. 1986. Dynamic positioning of large tankers at sea. In: OTC, editor. Proceedings of the Offshore Technology Conference; May 5-8; Houston, USA. OTC paper 5208. https://doi.org/10.4043/5208-ms

[15] Fossen TI, Strand JP. 2001. Nonlinear passive weather optimal positioning control (WOPC) system for ships and rigs: experimental results. Automatica. 37(5):701-715. https://doi.org/10.1016/s0005-1098(01)00006-1

[16] Fossen TI. 2011. Handbook of Marine Craft Hydrodynamics and Motion Control. John \& Wiley \& Sons. Shanghai. China. https://doi.org/10.1002/9781119994138

[17] Kim YS, Lee HB, Kim JH. 2017. Coordinated weathervaning control of two surface vessels in a tandem configuration. Ocean Engineering. 130:142-155. https://doi.org/10.1016/j.oceaneng.2016.11.046

[18] Kim YH, Jung DW, Cho SK, Sung HG. 2018. Experimental study on hydrodynamic characteristics and operational feasibility of floating LNG bunkering terminal moored side-by-side with LNG Carrier and two LNG bunkering shuttles. Ships and Offshore Structures. 13(5):504-518. https://doi.org/10.1080/17445302.2018.1430099

[19] Jung DW, Kim YH, Cho SK, Sung HG. 2018. Experimental study on floating LNG bunkering terminal for assessment of loading and offloading performance. Journal of Ocean Engineering and Technology. 32(1):51-61. https://doi.org/10.26748/ksoe.2018.2.32.1.051

[20] KRISO. 2016. Report of development of technology for floating offshore LNG bunkering system. Korea: Ministry of Oceans and Fisheries. No.: MEG0101-EA1006.

Submitted: $\quad 11.01 .2020$

Accepted: $\quad 28.9 .2020$
Yun Ho Kim

Dong Woo Jung

Hyung DO Song

Young Uk Won

Dong Ho Jung

Korea Research Institute of Ships \&

Ocean Engineering, Daejeon, South Korea 